\begin{tabular}{|c|c|c|c|c|c|}
\hline MUNIBE Antropologia-Arkeologia & $n^{\circ} 69$ & $5-20$ & DONOSTIA & 2018 & ISSN 1132-2217 • eISSN 2172-4555 \\
\hline
\end{tabular}

\title{
Anthracological data from Middle Palaeolithic contexts in Iberia: What do we know?
}

\section{Datos antracológicos de contextos del Paleolítico medio en la Península Ibérica: ¿Qué sabemos?}

KEY WORDS: Charcoal analysis, Neanderthals, Paleoenvironment, Marine Isotopic Stage, Iberian Peninsula.

PALABRAS CLAVES: Antracología, Neandertales, Paleoambiente, Estadio Isotópico Marino, península Ibérica. GAKO-HITZAK: Antrakologia, Neanderthalak, paleogiroa, itsasoko egoera isotopikoa, Iberiar penintsula.

Paloma VIDAL-MATUTANO(a,b,*)

\begin{abstract}
In this paper, a state of the art regarding the available anthracological data from Middle Palaeolithic contexts in Iberia is presented. The information retrieved is still very scarce and fragmented, as many Iberian areas present palaeobotanical gaps leading to the lack of information regarding local landscape dynamics. The use of different sampling methods to recover wood charcoal remains is a decisive factor which hampers the comparative study, although the dominance of Pinus nigra-sylvestris (black-scots pine) is recorded since, at least, Marine Isotopic Stage 6 . This would indicate the widespread presence of cryophilous pine woodlands during the Upper Pleistocene in Iberia pointing to the prevalence of supramediterranean conditions (MAT $=8-13^{\circ} \mathrm{C}$ ). This state of the art aims to contribute to our understanding of Upper Pleistocene Iberian landscapes based on Neanderthal firewood gathering activities.
\end{abstract}

\section{RESUMEN}

En este trabajo se presenta un estado de la cuestión relativo a los datos antracológicos disponibles para el Paleolítico medio en la península Ibérica. La información obtenida es todavía muy escasa y fragmentada, existiendo muchas áreas peninsulares con lagunas de datos relativos a las dinámicas de la vegetación local. La utilización de métodos de muestreo diferentes en la recuperación de los restos antracológicos constituye un factor decisivo que dificulta el estudio comparativo, aunque el dominio de Pinus nigra-sylvestris (pino salgareño-albar) está documentado desde, al menos, el Estadio Isotópico Marino 6. Ello indicaría la presencia de extensiones de bosques de pinos criófilos durante el Pleistoceno superior en la península lbérica con el predominio de condiciones supramediterráneas $\left(\mathrm{TMA}=8-13^{\circ} \mathrm{C}\right)$. Este estado de la cuestión pretende contribuir a una mayor comprensión de los paisajes ibéricos durante el Pleistoceno superior a partir de la recolección de leña por parte de los grupos neandertales.

\section{LABURPENA}

Lan honetan, Iberiar penintsulako Paleolitiko ertainerako eskuragarri dauden datu antrakologikoei buruzko gaur egungo egoera azaltzen da. Lortutako informazioa oraindik ere oso urria da eta zatituta dago eta bertako landarediaren dinamikei buruzko datuetan hutsuneak dituzten eremu ugari daude penintsulan. Hondakin antrakologikoak berreskuratzeko garaian laginketa-metodo ezberdinak erabiltzea faktore erabakigarria da eta horrek alderaketa egitea zailtzen du. Dena den, Pinus nigra-sylvestris (Larizio-pinua) zuhaitzaren eremua gutxienez itsasoko egoera isotopiko 6tik dokumentatuta dago gutxienez. Horrek agerian uzten du Iberiar penintsulan goi mailako Pleistozenoan pinu kriofiloen basoak zeudela eta baldintza suprameditarraneoak zirela nagusi (TMA $\left.=8-13^{\circ} \mathrm{C}\right)$. Gaur egungo egoera honen helburua Neanderthalen taldeek egindako egur-bilketatik abiatuta goi mailako Pleistozeno garaiko paisaia iberiarrak hobeto ulertzen laguntzea da.

\section{INTRODUCTION}

Anthracology or charcoal analysis traditionally focuses on the botanical identification of charcoal fragments in order to obtain palaeoenvironmental
(Badal, 1992; Badal and Heinz, 1989, 1991; Chabal, 1992, 1997; Figueiral, 1992; Thiébault, 1988) and palaeoeconomical data (Allué et al., 2016; Caruso et

\footnotetext{
(a) PREMEDOC Research Group, Universitat de València, Departament de Prehistòria, Arqueologia i Història Antiga, Blasco Ibáñez 28 46010, València, Spain.

(b) Université Côte-d'Azur CEPAM, CNRS, France

(*) Corresponding author: Tel. +34 963983894 E-mail address: paloma.vidal@uv.es. Avenida Blasco Ibáñez, 28, 46010, Valencia (Spain).
}

Abbreviations: MIS: Marine isotopic stage; MAT: Mean annual temperature. 
al., 2014; Chrzazvez et al., 2014; Henry and Boboeuf, 2016; Henry and Théry-Parisot, 2014; Théry-Parisot, 2001, 2002; Théry-Parisot et al., 2010; Vidal-Matutano, 2017; Vidal-Matutano et al., 2017b). Anthracological remains have the potential to offer palaeoecological and palaeoeconomical information according to the scattered or concentrated distribution of the sampled wood charcoal, respectively. Concentrated anthracological assemblages refer to punctual carbonization of wood by natural or anthropogenic causes. In Palaeolithic sites, the most common concentrated contexts are combustion structures, which are the result of the last firewood collecting actions in the supply area. These assemblages provide interesting palaeoeconomical data regarding firewood acquisition strategies by human groups. On the other hand, scattered anthracological assemblages contribute to meaningful palaeoenvironmental data as they are the result of several combustion events during different human occupations. In this sense, we must take into account that wood charcoal fragments recovered at archaeological sites are the result of firewood selection criteria and, as a consequence, a complete picture of the local flora cannot be achieved. However, as an average representation of cumulative processes resulting from an undefined number of occupation events, scattered charcoal fragments are mostly representative of the woody local flora (Badal and Heinz, 1991; Chabal, 1997).

The emergence of the first systematic approach in charcoal analyses with the École de Montpellier, during the $80 \mathrm{~s}$ and $90 \mathrm{~s}$, led to the consolidation of the anthracological methodology and the palaeoecological representativeness of charcoal assemblages (Chabal, 1997). This methodological establishment allowed the development of several regional studies in France, Italy, Portugal or Spain (Badal, 1990; Bazile-Robert, 1979; Chabal, 1991, 1982; Figueiral, 1990; Heinz, 1988). Recently, other research approaches have been applied to charcoal analysis from a palaeoeconomical point of view based on experimentation, observation of microanatomical features due to biological or mechanical processes, dendrological studies or spatial analysis of anthracological remains (Carrión, 2007; Caruso et al., 2014; Henry and Théry-Parisot, 2014; Marguerie and Hunot, 2007; Théry-Parisot and Costamagno, 2005; Théry-Parisot and Henry, 2012; Vidal-Matutano, 2017; Vidal-Matutano et al., 2017a; Vidal-Matutano et al., 2017b). Nevertheless, despite the great advances made in anthracology, there are still very few published studies in Middle Palaeolithic contexts from Iberia (Allué et al., 2017; Allué et al., 2018; Badal et al., 2012a; Daura et al., 2015; Gale and Garruthers, 2000; Ros, 1985; Uzquiano, 1992, 2005; Uzquiano et al., 2008; Uzquiano et al., 2012; Vidal-Matutano, 2017; Vidal-Matutano et al., 2015; Vidal-Matutano et al., 2017a; Vidal-Matutano et al., 2017b; Vidal-Matutano et al., 2018; Zilhao et al., 2016) although they constitute valuable data to go further in our understanding of Iberian Middle Palaeolithic landscapes

\subsection{Middle Palaeolithic: diversity of landsca- pes and climates}

Upper Pleistocene is framed between ca. $126 \mathrm{ka}$ and 11.7 ka BP (Rasmussen et al., 2006, 2014). During this long period of time the climate and the landscape did not remain stable, but continuous climatic changes with varying intensity depending on periods and regions had place. Thus, the first of the marine isotopic stages that took place during the Upper Pleistocene was MIS 5 or Last Interglacial (Woillard, 1978), a period characterized by the presence of a minimum ice volume at high latitudes between ca. $126-75 \mathrm{ka} \mathrm{BP}$. The climatic fluctuations recorded during MIS 5 have led to their division into cold ( $5 d$ and $5 b$ ) and warm episodes (5c and $5 a$ ) together with the warmest interval (5e or Eemian) where similar climatic conditions to the present were developed (Sánchez Goñi et al., 1999; Shackleton, 1969). MIS 4 glacial period (ca. 75 - 60 ka BP) was characterized by a minimum of summer insolation on the northern latitudes producing a greater extension of polar ice caps and a descent of the sea level (Rasmussen et al., 2006; Sánchez Goñi and d'Errico, 2005). Finally, MIS 3 period (ca. 60 - 25 ka BP) was not less variable from a climatic point of view, since it was an interstate period identified by the alternation of temperate cycles or Dansgaard-Oeschger events (Dansgaard et al., 1993) and cold phases or Heinrich events (Heinrich, 1988). Therefore, Middle Palaeolithic human groups lived in several environments occupying different European altitudes and latitudes. Biogeographic characteristics of each area would have led to the recognition of a plurality of landscapes and biotopes where Neanderthal groups may have met their daily needs. The aim of this paper is to collect the available anthracological data during the Middle Palaeolithic in Iberia. This state of the art regarding Middle Palaeolithic charcoal analyses will allow us obtaining significant palaoenvironmental data based on firewood gathering by Neanderthal groups in their surroundings. In addition, data review from these contexts will enable to assess the availability of macrobotanical data and the existing gaps in Iberia.

\section{MATERIAL \& METHODS}

Regarding the available Middle Palaeolithic anthracological data in Iberia, the first consideration that should be highlighted is that it still constitutes very limited and fragmented information. Whether due to the poor organic preservation at many sites or a lack of interest, the fact remains that the available data concerning firewood use for Middle Palaeolithic contexts is still scarce (Théry-Parisot et al., 2010). Additionally, some Iberian regions gather most of the published studies while other areas present a total gap. Although this fragmented data could be related to the existence of regions with a deeper tradition in charcoal analyses, the methodological prejudices and the lack of interest in obtaining palaeobotanical data have contributed to 
this situation. Another point concerning the sampling methods used should be highlighted. The diversity of the applied sampling methods hampers a quantitative and qualitative anthracological data comparison between sites. Although systematical recovering methods based on the flotation of sediments have been increased in the last decades since the École de Montpellier studies (Badal and Heinz, 1991; Chabal, 1992, 1997), many wood charcoal assemblages are recovered still today by hand-picking sampling leading to biased results. In addition, another difficulty found in some published charcoal analyses has been the non-mention of the recovery method applied, which may hinder interpretation of data.

Table 1 includes the Middle Palaeolitic sites considered in this work. These archaeological sites, belonging to MIS 6 - 3, provide available palaeoenvironmental data for these chronologies and the most representative level (in terms of number of wood charcoal fragments identified) of each site has been selected. Those sites in which the anthracological results have been published quantitatively are reflected in the Table. In this sense, those sites with quantitative data presenting, at least, 100 wood charcoal fragments identified in a stratigraphic unit have been graphically represented. Additionally, those sites without quantitative data published appear at Table 1 following a presence / absence system. Finally, other factors such as longitude, latitude and altitude ( $m$ a.s.I.) have been recorded for each site, as they are influential variables in the composition of local flora (Rivas Martínez, 1987). In addition, the sampling method applied at each site has also been recorded.

Although the discussion of this work is not focused on pollen data obtained for these chronologies, a comparative study of how many Iberian Middle Palaeolithic contexts presenting palynological, anhracological or both proxies analyses has been considered. Regarding this, palynological data tend to be more abundant than charcoal analyses (Fig. 1). MIS 3 period, the moment

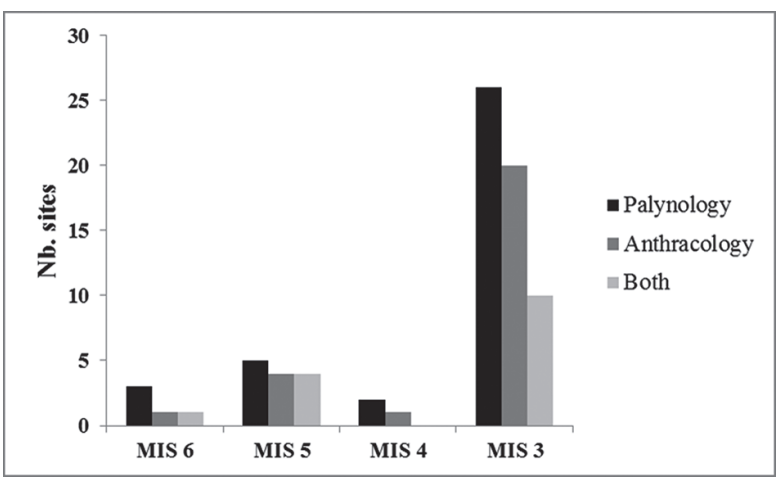

Fig. 1. Number of Iberian Middle Palaeolithic sites presenting palynological anthracological and both archaeobotanical proxies. / Número de yacimientos del Paleolítico medio de la Península Ibérica con datos palinológicos, antracológicos y de ambos proxies. when there is greater available palaeobotanical data compared to previous periods, clearly reflects this dynamic with a total of 10 sites presenting data from both proxies. This indicates that the application of different archaeobotanical proxies to obtain complementary data concerning landscape dynamics is not a widespread practice yet.

The identified flora at the published Middle Palaeolithic sites has been classified into five main groups:

- Cryophilous pines, mostly identified as Pinus nigra-sylvestris. Nowadays, Pinus sylvestris and Pinus nigra can be found above $1000-1200 \mathrm{~m}$ asl occupying the supramediterranean and/or oromediterranean mountains of Iberia, although Pinus sylvestris requires cooler conditions than Pinus nigra and mostly grows in the oromediterranean bioclimatic belt (Rivas Martínez, 1987).

- Warm pines, identified as Pinus pinea, Pinus halepensis or Pinus pinea-pinaster. These are pine species with warmer bioclimatic requirements than the previous ones, documented generally at archaeological sites located south of the $40^{\circ} \mathrm{N}$ parallel (Badal et al., 2012b).

- Juniper forest and heliophilous taxa. Although the distinction between the different species of the Juniperus genus (J. oxycedrus, J. phoenicea, J. communis, J. thurifera) cannot be reached based on the anatomical observation, they are all species showing a great resistance to conditions of extreme aridity. For this reason, other taxa with heliophilous nature such as woody legumes, Ephedra o Artemisia have also been included in this group.

- Mixed forest, composed by sclerophyllous and deciduous taxa like Rosaceae species, Pistacia, Labiatae, Rhamnus or Cistaceae. In northern Iberian sites this group includes Eurosiberian taxa like Corylus avellana or Castanea sativa, which are only present in these latitudes.

- Ripisylve, composed by taxa present in the bottom of the valleys or in humid areas (Fraxinus, Salix-Populus, Ulmus).

Along with these categories, other taxa have been considered separately such as Betula (Birch), Quercus evergreen (evergreen oaks), Quercus deciduous (deciduous oaks), Olea europea (Olive tree), Acer (Maple) and Buxus sempervirens (Bow). Although these taxa could be included in the previous groups, their abundance in some regions and / or their significance as bioindicators has determined their individual consideration.

\section{RESULTS \& DISCUSSION}

\subsection{Available anthracological data}

Regarding the first chronological period considered (MIS 6), there are still few known archaeological 


\begin{tabular}{|c|c|c|c|c|c|c|c|c|c|c|}
\hline ID & Site & Location & Latitude & Longitude & $\mathrm{m}$ asl & MIS & Level & $\mathbf{P}$ & $\mathrm{Ch}$ & Method \\
\hline 1 & Abric del Pastor & Alcoi, Alicante & 38,7131 & $-0,4909$ & 820 & 4 & IV & & $x$ & $\mathrm{~F}$ \\
\hline 2 & Abric Romaní & Capellades, Barcelona & 41,3143 & 1,4128 & 300 & 3 & $\mathrm{Ja}$ & $x$ & $x$ & $\mathrm{H}$ \\
\hline 3 & Abrigo de la Quebrada & Chelva, Valencia & 39,4825 & $-1,0049$ & 708 & 3 & IV & $x$ & $x$ & $\mathrm{~F}$ \\
\hline 4 & Abrigo de Navalmaillo & Pinilla del Valle, Madrid & 40,9237 & $-3,8081$ & 1114 & 4 & $\mathrm{~F}$ & $x$ & & \\
\hline 5 & Cueva del Castillo & Puente Viesgo, Cantabria & 43,1730 & $-3,5803$ & 195 & 3 & 20 & & $x$ & $\mathrm{~F}$ \\
\hline 6 & Cova 120 & La Garrotxa, Girona & 42,1706 & 2,5774 & 460 & 3 & IV & $x$ & $x$ & $\mathrm{H}$ \\
\hline 7 & Cova Beneito & Muro, Alicante & 38,802 & $-4,4752$ & 650 & 3 & $x$ & $x$ & & \\
\hline 8 & Cova Bolomor & Tavernes de la Valldigna, Valencia & 39,0581 & $-0,2524$ & 100 & 6 & $\mathrm{XI}$ & $x$ & $x$ & DS \\
\hline 9 & Cova de l'Arbreda & Serinyà, Girona & 42,0936 & 2,4449 & 200 & 3 & $\mathrm{H}$ & $x$ & $x$ & $\mathrm{~F}$ \\
\hline 10 & Cova del Rinoceront & Castelldefels, Barcelona & 41,1624 & 1,5739 & 25 & 5 & 1 & $x$ & $x$ & $\mathrm{H}$ \\
\hline 11 & Cova del Coll Verdaguer & Cervelló, Barcelona & 41,3888 & 1,9554 & 450 & 3 & 1 & & $x$ & $\mathrm{H}$ \\
\hline 12 & Cova del Toll & Moià, Barcelona & 41,8112 & 2,0959 & 745 & 3 & IV & $x$ & & \\
\hline 13 & Cova Foradà & Oliva, Alicante & 38,8930 & $-0,1028$ & 100 & 3 & $\mathrm{C} 5$ & & $x$ & $\mathrm{H}$ \\
\hline 14 & Cova Gran & Santa Linya, Lleida & 41,9015 & 0,8120 & 385 & 3 & $\mathrm{~S} 1 \mathrm{C}$ & $x$ & $x$ & $\mathrm{H}$ \\
\hline 15 & Covalejos & Piélagos, Cantabria & 43,2348 & $-3,5558$ & 105 & 3 & $\mathrm{H}-\mathrm{J}$ & $x$ & $x$ & $\mathrm{~F}$ \\
\hline 16 & Cueva Bajondillo & Torremolinos, Málaga & 36,6236 & $-4,4916$ & 10 & 6 & $\mathrm{XIX}$ & $x$ & & \\
\hline 16 & Cueva Bajondillo & Torremolinos, Málaga & 36,6236 & $-4,4916$ & 10 & 5 & XVIII & $x$ & & \\
\hline 16 & Cueva Bajondillo & Torremolinos, Málaga & 36,6236 & $-4,4916$ & 10 & 4 & $\mathrm{XVII}$ & $x$ & & \\
\hline 16 & Cueva Bajondillo & Torremolinos, Málaga & 36,6236 & $-4,4916$ & 10 & 3 & $\mathrm{XVI}$ & $x$ & & \\
\hline 17 & Cueva Antón & Mula, Murcia & 38,0547 & $-1,2947$ & 355 & 5 & AS5 & $x$ & $x$ & $\mathrm{~F}$ \\
\hline 18 & Cueva de Abauntz & Arraitz, Navarra & 43,0061 & $-1,6599$ & 650 & 3 & $\mathrm{H}$ & $x$ & & \\
\hline 19 & Cueva de Amalda & Cestona, Gipuzkoa & 43,2385 & $-2,2535$ & 110 & 3 & VII & $x$ & & \\
\hline 20 & Cueva de Arrillor & Araba, País Vasco & 42,9529 & $-2,7593$ & 710 & 3 & AMK & $x$ & & \\
\hline 21 & Cueva de la Buena Pinta & Pinilla del Valle, Madrid & 40,9437 & $-3,4081$ & 1114 & 3 & III & $x$ & & \\
\hline 22 & Cueva de la Carihuela & Piñar, Granada & 38,0915 & $-3,3546$ & 1020 & 3 & $\mathrm{VI}$ & $x$ & & \\
\hline 23 & Cueva de los Moros de Gabasa & Peralta de Calasanz, Huesca & 42,0181 & 0,3752 & 780 & 3 & G & $x$ & & \\
\hline 24 & Cueva del Boquete de Zafarraya & Málaga & 36,5704 & $-4,0738$ & 1022 & 3 & II & $x$ & $x$ & $\mathrm{H}$ \\
\hline 25 & Cueva del Camino & Pinilla del Valle, Madrid & 40,9281 & $-3,8202$ & 1114 & 5 & 5 & $x$ & $x$ & $\mathrm{~F}$ \\
\hline 26 & Cueva del Conde & Tuñón, Santo Adriano & 43,1723 & $-5,5854$ & 180 & 3 & $20 \mathrm{~A}$ & & $x$ & $\mathrm{~F}$ \\
\hline 27 & Cueva del Otero & Voto, Cantabria & 43,3229 & $-3,512$ & 60 & 3 & IX & $x$ & & \\
\hline 28 & Cueva Morín & Villaescusa, Cantabria & 43,3499 & $-3,8704$ & 57 & 3 & $X I I$ & $x$ & & \\
\hline 29 & Cueva Perneras & Lorca (Murcia) & 37,7012 & $-1,7121$ & 105 & 3 & IX & $x$ & & \\
\hline 30 & El Esquilleu & Cillorigo de Liébana, Cantabria & 43,1250 & $-4,3526$ & 350 & 3 & $X I I I$ & $x$ & $x$ & $\mathrm{~F}$ \\
\hline 31 & El Salt & Alcoi, Alicante & 38,6876 & $-0,5082$ & 680 & 3 & $\mathrm{XB}$ & $x$ & $x$ & $\mathrm{~F}$ \\
\hline 32 & Gorham's Cave & Gibraltar & 36,0713 & $-5,2031$ & 10 & 3 & IV & $x$ & $x$ & $\mathrm{~F}$ \\
\hline 33 & Gruta da Oliveira & Torres Novas, Portugal & 39,3019 & $-8,3655$ & 115 & 3 & 14-15 & & $x$ & $\mathrm{H}$ \\
\hline 34 & Higueral de la Valleja & Arcos de la frontera, Cádiz & 36,4120 & $-5,4622$ & 190 & 3 & $\mathrm{VI}$ & & $x$ & $\mathrm{H}$ \\
\hline 35 & Labeko Koba & Mondragón, Gipuzkoa & 43,0627 & $-2,4923$ & 246 & 3 & IX & $x$ & & \\
\hline 36 & Las Fuentes de San Cristóbal & Veracruz, Huesca & 42,2003 & 0,3425 & 820 & 3 & $\mathrm{G}$ & & $x$ & $\mathrm{H}$ \\
\hline 37 & Lezetxiki & Arrasate, Gipuzkoa & 43,0395 & $-2,4184$ & 345 & 6 & $\mathrm{R}$ & $x$ & & \\
\hline 38 & Roca dels Bous & La Noguera, Lleida & 41,8408 & 0,8294 & 275 & 3 & R3 & & $x$ & $\mathrm{H}$ \\
\hline 39 & Sima de las Palomas & Torre Pacheco, Murcia & 37,7969 & $-0,892$ & 80 & 3 & II & $x$ & & \\
\hline 40 & Teixoneres & Moià, Barcelona & 41,8100 & 2,0971 & 900 & 5 & II & $x$ & $x$ & $\mathrm{H}$ \\
\hline 41 & Tossal de la Font & Vilafamés, Castellón & 40,0920 & $-0,0722$ & 357 & 3 & $\| \mathrm{A}$ & $x$ & $x$ & $\mathrm{H}$ \\
\hline 42 & Vanguard cave & Gibraltar & 36,0713 & $-5,2031$ & 10 & 3 & IV & $x$ & $x$ & - \\
\hline
\end{tabular}

Table 1: Middle Palaeolithic sites considered and the available anthracological data. CrP = Cryophilous pines; WP = Warm pines; Jun = Juniperus and heliophilous taxa; $\mathrm{Be}=$ Betula; $\mathrm{Q}=$ Quercus sp.; $\mathrm{Qe}=$ Quercus evergreen; $\mathrm{Qd}=$ Quercus deciduous; $\mathrm{Mf}=$ Mixed forest; $\mathrm{O}=$ Olea europaea; $\mathrm{Ac}=\mathrm{Acer} \mathrm{sp}$.; $\mathrm{Bx}=$ Buxus sempervirens and $\mathrm{R}=$ Ripisylve $/$ Yacimientos del Paleolítico medio considerados y datos antracológicos disponibles. $\mathrm{CrP}=\mathrm{Pinos}$ criófilos; WP $=$ Pinos cálidos; Jun = Juniperus y taxones heliófilos; $\mathrm{Be}=$ Betula; $\mathrm{Q}=$ Quercus sp.; $\mathrm{Qe}=$ Quercus perennifolio; $\mathrm{Qd}=$ Quercus caducifolio; $\mathrm{Mf}=\mathrm{Bosque}$ mixto; $\mathrm{O}=$ Olea europaea; $\mathrm{Ac}=$ Acer sp.; $\mathrm{Bx}=$ Buxus sempervirens y $\mathrm{R}=$ Rivera." 


\begin{tabular}{|c|c|c|c|c|c|c|c|c|c|c|c|c|c|c|}
\hline References & Nb. Charcoal & Min. Taxa & $\mathrm{CrP}$ & WP & Jun & $\mathrm{Be}$ & $\mathbf{Q}$ & Qe & Qd & Mf & 0 & Ac & $\mathrm{Bx}$ & $\mathbf{R}$ \\
\hline Vidal-Matutano et al. 2015 & 957 & 16 & 105 & & 500 & & 89 & 87 & 5 & 126 & & & & 45 \\
\hline Allué 2002; Burjachs 2012 & 652 & 2 & 651 & & & & & & & & & & & 1 \\
\hline Badal et al 2012a & 182 & 2 & 181 & & & & & 1 & & & & & & \\
\hline \multicolumn{15}{|l|}{ Ruiz Zapata et al 2008} \\
\hline Uzquiano 1992 & 865 & 11 & 39 & & & 784 & & & & 40 & & & & 2 \\
\hline Agustí et al. 1991 & 59 & 8 & 26 & & 11 & & & 1 & 7 & 14 & & & & \\
\hline \multicolumn{15}{|l|}{ Carrión 1992} \\
\hline Vidal-Matutano et al. 2017a & 14 & 2 & 12 & & 2 & & & & & & & & & \\
\hline Ros 1985 & 393 & 5 & 212 & & & & & & & 74 & & 102 & & 5 \\
\hline Daura et al 2015 & 7 & 2 & & & & & & & & 7 & & & & \\
\hline Allué et al. 2017 & 402 & 3 & 350 & & & & & & 4 & 48 & & & & \\
\hline \multicolumn{15}{|l|}{ Rosell et al 2014} \\
\hline Badal 1984 & 33 & 8 & 12 & & 3 & & & 5 & & 11 & & 2 & & \\
\hline ez-Moreno et al 2010; Allué et al. 2018 & 102 & 2 & 101 & & & & & & 1 & & & & & \\
\hline Uzquiano 2005 & - & 6 & $x$ & & & $x$ & & & & $x$ & & & & \\
\hline \multicolumn{15}{|l|}{ Cortés-Sánchez et al 2008} \\
\hline \multicolumn{15}{|l|}{ Cortés-Sánchez et al 2008} \\
\hline \multicolumn{15}{|l|}{ Cortés-Sánchez et al 2008} \\
\hline \multicolumn{15}{|l|}{ Cortés-Sánchez et al 2008} \\
\hline Zilhao et al. 2016 & 621 & 13 & 13 & 336 & 138 & & 78 & 15 & 22 & & & & & 19 \\
\hline \multicolumn{15}{|l|}{ Utrilla et al 2014} \\
\hline \multicolumn{15}{|l|}{ Dupré 1988} \\
\hline \multicolumn{15}{|l|}{ Sáenz de Buruaga 2014} \\
\hline \multicolumn{15}{|l|}{ Ruiz Zapata et al 2008} \\
\hline \multicolumn{15}{|l|}{ Carrión and Dupré 1994} \\
\hline \multicolumn{15}{|l|}{ González-Sampériz 2004} \\
\hline Lebreton et al 2006 & - & 5 & $x$ & & $x$ & & & $x$ & & $x$ & $x$ & & & \\
\hline Arsuaga et al 2012 & 249 & 6 & 226 & & & 17 & & & 1 & 3 & & & & 2 \\
\hline Uzquiano et al 2008 & 373 & 16 & 232 & & 17 & 11 & & & & 95 & & & & 18 \\
\hline \multicolumn{15}{|l|}{ Leroi-Gourhan 1966} \\
\hline \multicolumn{15}{|l|}{ Sánchez-Goñi 1994} \\
\hline \multicolumn{15}{|l|}{ Carrión and Dupré 1994} \\
\hline Uzquiano et al 2012 & - & 6 & $x$ & & & $x$ & & & & $x$ & & & & $x$ \\
\hline Vidal-Matutano et al. 2018 & 2999 & 12 & 2516 & & 25 & & 54 & 4 & 2 & 21 & & 335 & 36 & 6 \\
\hline n et al 2008; Gale and Garruthers 2000 & 184 & 7 & $x$ & $x$ & $x$ & & & & & $x$ & $x$ & & & \\
\hline Badal et al 2012a & 41 & 2 & 37 & & 4 & & & & & & & & & \\
\hline Jennings et al 2009 & - & 2 & & $x$ & & & & & & & $x$ & & & \\
\hline \multicolumn{15}{|l|}{ Sánchez-Goñi, 1991; Iriarte 2000} \\
\hline Allué 2002 & 18 & 5 & 7 & & 2 & & & & 1 & 2 & & & 6 & \\
\hline \multicolumn{15}{|l|}{ Arrizabalaga 2014} \\
\hline Terradas et al 1993 & 36 & 2 & 25 & & 11 & & & & & & & & & \\
\hline \multicolumn{15}{|l|}{ Carrion et al 2003} \\
\hline López-García et al 2012 & 4 & 3 & 2 & 1 & & & & & 1 & & & & & \\
\hline Olària et al 2004-2005 & - & 1 & & $\mathrm{cf}$ & & & & & & & & & & \\
\hline h et al 2008; Gale and Garruthers 2000 & 49 & 8 & $x$ & $\mathrm{x}$ & & & & & & $x$ & $x$ & & & $x$ \\
\hline
\end{tabular}


sites with archaeobotanical data (Fig. 2). Only Bolomor Cave (level XI) provides wood charcoal data for this period, although it constitutes a reduced anthracological assemblage. At Bolomor Cave, undetermined wood charcoal fragments are abundant based on the small size of the fragments $(<1 \mathrm{~mm})$ and the poor preservation, which is not the optimal to guarantee botanical determination at a higher resolution (Vidal-Matutano et al., 2017a). Hence, the anthracological record from Bolomor Cave is not abundant enough to assess the presence of mixed plant formations that should have been more abundant taking into account the current biogeographical location of the site (100 $\mathrm{m}$ a.s.I.). Despite this, charcoal analysis from this site shed light on the characterisation of the landscape, with the presence of Pinus nigra-sylvestris (cryophilous pines) pointing to the prevalence of meso-supramediterranean conditions (mean annual temperature [MAT] of $8-17^{\circ} \mathrm{C}$ ) in Eastern Iberia during MIS 6 (Vidal-Matutano et al., 2017a).

During MIS 5 period, the number of sites is still scarce (Fig. 3). Available data is very fragmented and come from Cueva del Camino, level 5 (Arsuaga et al., 2012), Teixoneres, level II (López-García et al., 2012), Cova del Rinoceront, level I (Daura et al., 2015) and Cueva Antón, level AS5 (Zilhão et al., 2016). At Cueva del Camino and Teixoneres, both located at an altitude higher than or equal to $900 \mathrm{~m}$ a.s.l., the dominance of cryophi- lous pines is recorded together with the presence of other taxa like birch or mixed plant formations of Maloideae (Rosaceae family) and Quercus sp. deciduous. However, data from Teixoneres should be interpreted with caution since the analysed assemblage is too scarce due to wood charcoal recovering by hand-picking methods $(n=4)$. The same observation can be argued with respect to Cova del Rinoceront, as only a limited wood charcoal assemblage has been recovered $(n=$ 7). Anthracological data from Cueva Antón, level AS5, is significantly different from the previous sites. At this site, although cryophilous pines are present at the record, the charcoal assemblage indicates open Aleppo pine forests (Pinus halepensis) with juniper and some oak growing under climatic conditions similar to present. The differences observed in flora composition between Cueva del Camino and Cueva Antón may be due to differences in latitude and altitude, but also because the archaeological levels could be framed in warmer or colder sub-phases of MIS 5.

During MIS 4 period, a vacuum regarding anthracological data is documented with the exception of Abric del Pastor, level IV (Vidal-Matutano et al., 2015) (Fig. 4). This site shows more than half of the anthracological record dominated by junipers and heliophilous taxa together with cryophilous pines. Besides this, a heterogeneous mixed forest, evergreen / deciduous oaks and

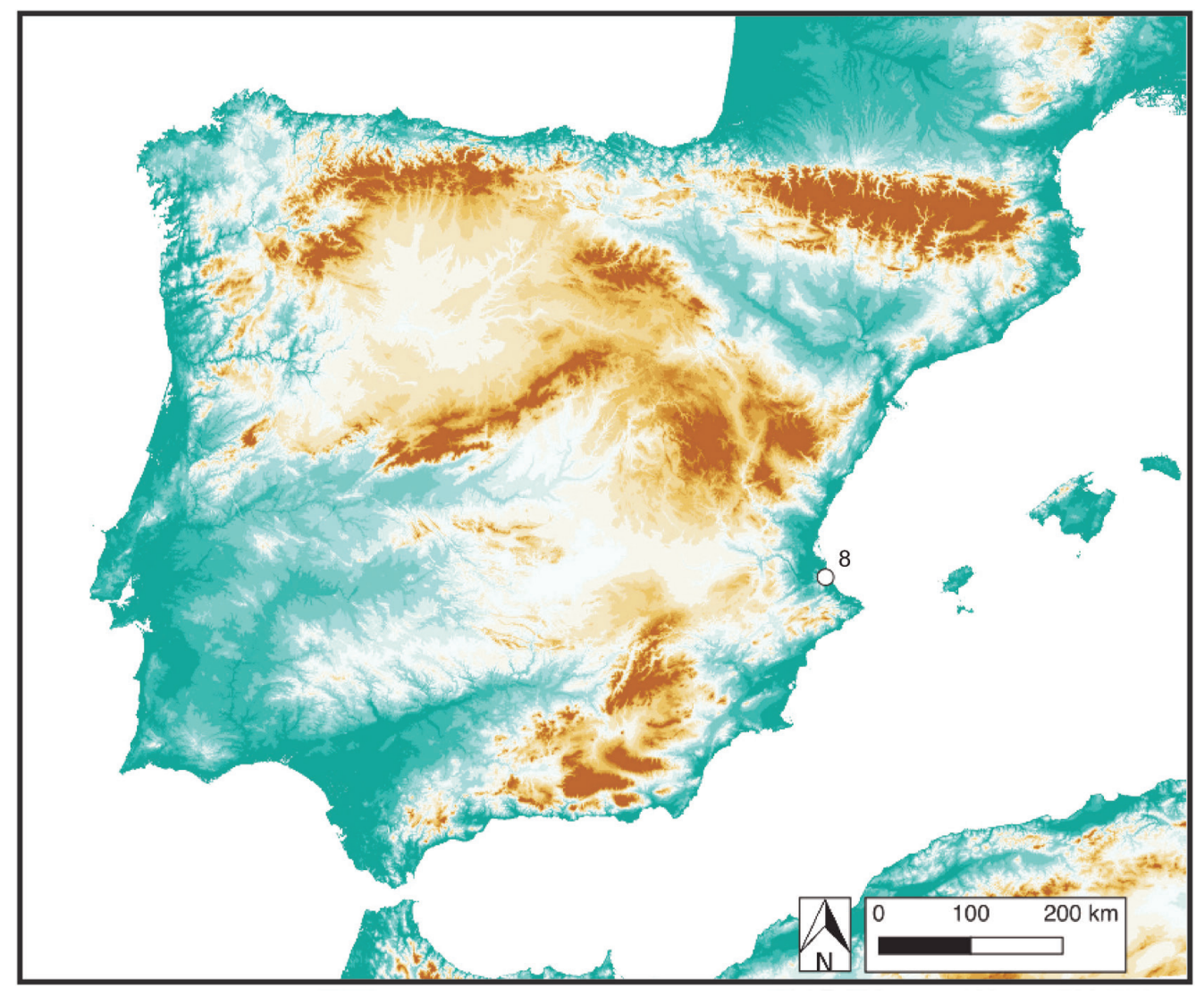

Fig. 2. Available anthracological data during MIS 6 period in Iberia. The number of the site refers to Table 1. / Datos antracológicos disponibles para el MIS 6 en la península lbérica. El número se corresponde con el sitio indicado en la Tabla 1 
25. Cueva del Camino, Level 5

$\mathrm{N}=249$

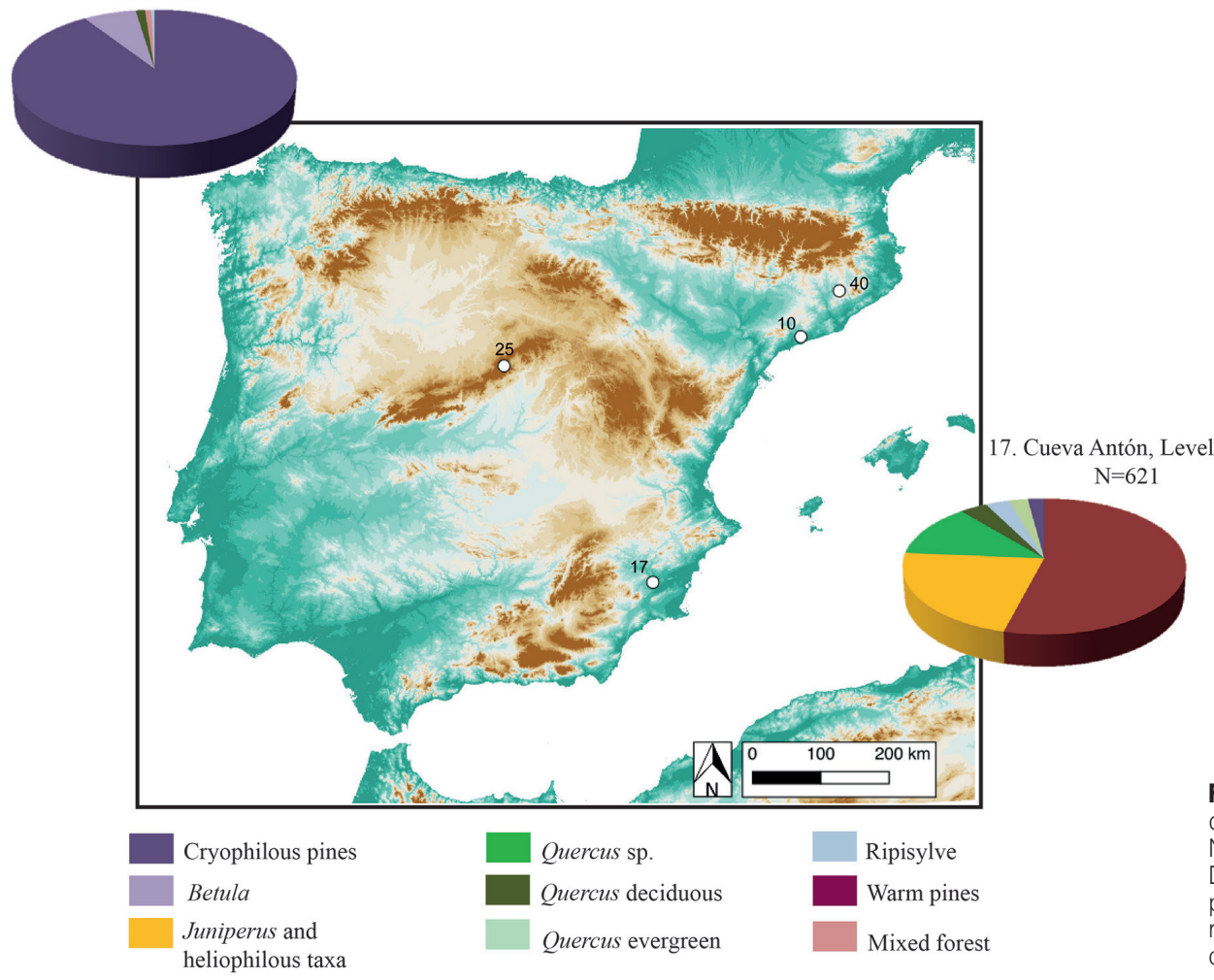

Fig. 3. Available anthracological data during MIS 5 period in Iberia. Numbers of sites refer to Table $1 . /$ Datos antracológicos disponibles para el MIS 5 en la península lbérica. Los números se corresponden con los sitios indicados en la Tabla 1

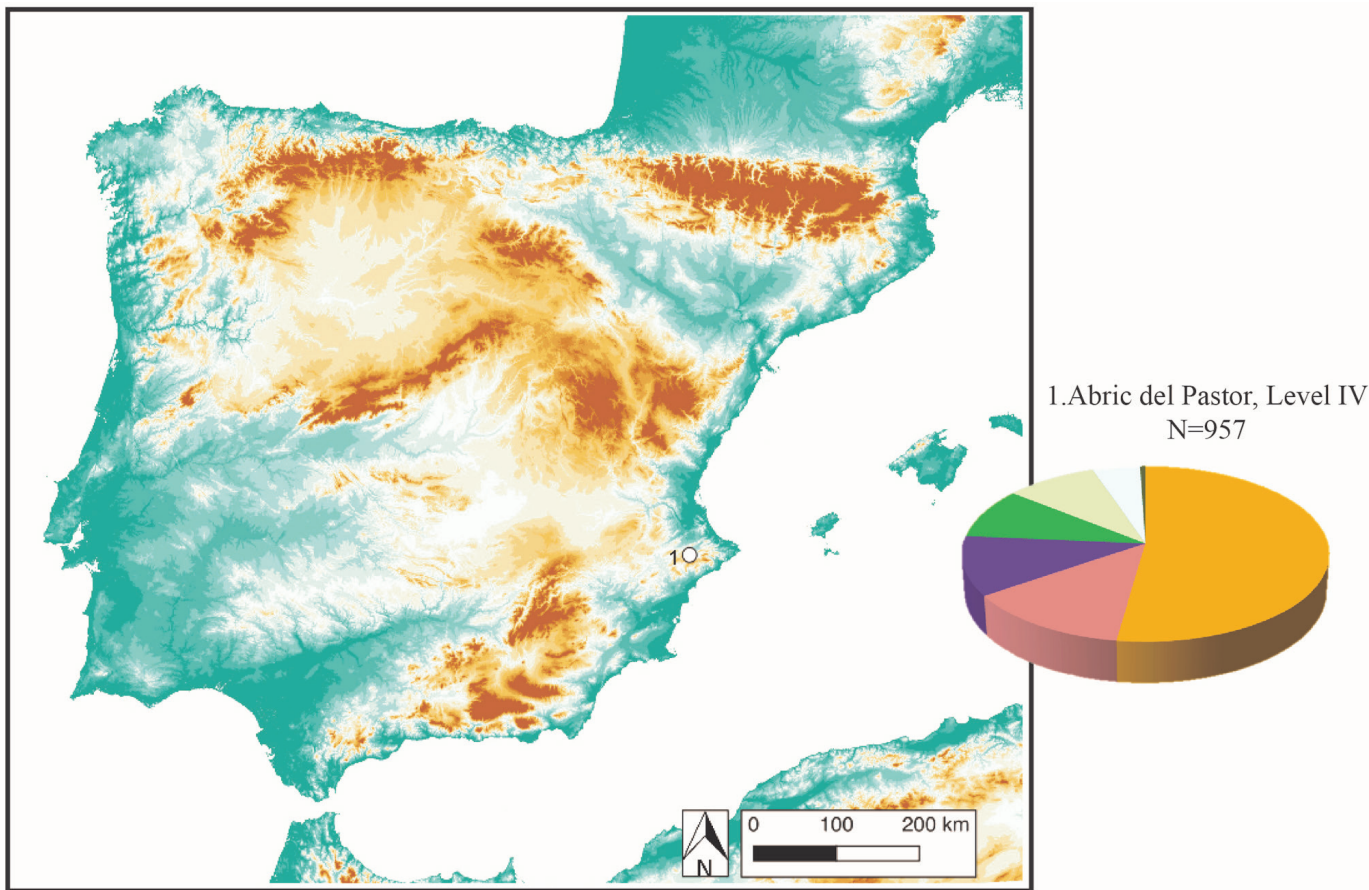

Cryophilous pines

Juniperus and heliophilous taxa
Quercus sp.

Quercus deciduous

Quercus evergreen
Fig. 4. Available anthracological data during MIS 4 period in Iberia. The number of the site refers to Table 1. / Datos antracológicos disponibles para el MIS 4 en la península lbérica. El número se corresponde con el sitio indicado en la Tabla 1. 
riverine taxa are also present, reflecting the typical plant formations present in a ravine like the one where Abric del Pastor is located. The predominance of juniper forest in this record is revealing prevailing arid, dry and cold conditions in, at least, eastern Iberia.

The number of known sites and the available anthracological data is noticeably increased since MIS 3 period (Fig. 5). In the north of Iberia (Fig. 5a), the available data from Cueva del Conde, level 20A (Uzquiano et al., 2008) and Cueva del Castillo, level 20 (Uzquiano, 1992) point out to the predominance of two taxa with different moisture requirements: the birch at Cueva del Castillo and cryophilous pines at Cueva del Conde. Uzquiano (1992) explains the differences in the dominant taxa based on the ecological characteristics of each area, i.e. the western area would be characterized by lower humidity conditions that would enable the development of cryophilous pine woodlands, while birch plant formations with higher moisture requirements would be present in the eastern area. It is significant to mention that the "mixed forest" category include the presence of Corylus avellana (hazel) and Castanea sativa (chestnut) at both sites, being Eurosiberian taxa with high humidity requirements that only grow at these latitudes (Costa et al., 2005). Complementary anthracological data, although not quantitatively available, come from Covalejos levels H-J (Uzquiano, 2005) and El Esquilleu level XIII (Uzquiano et al., 2012) which indicate the presence of
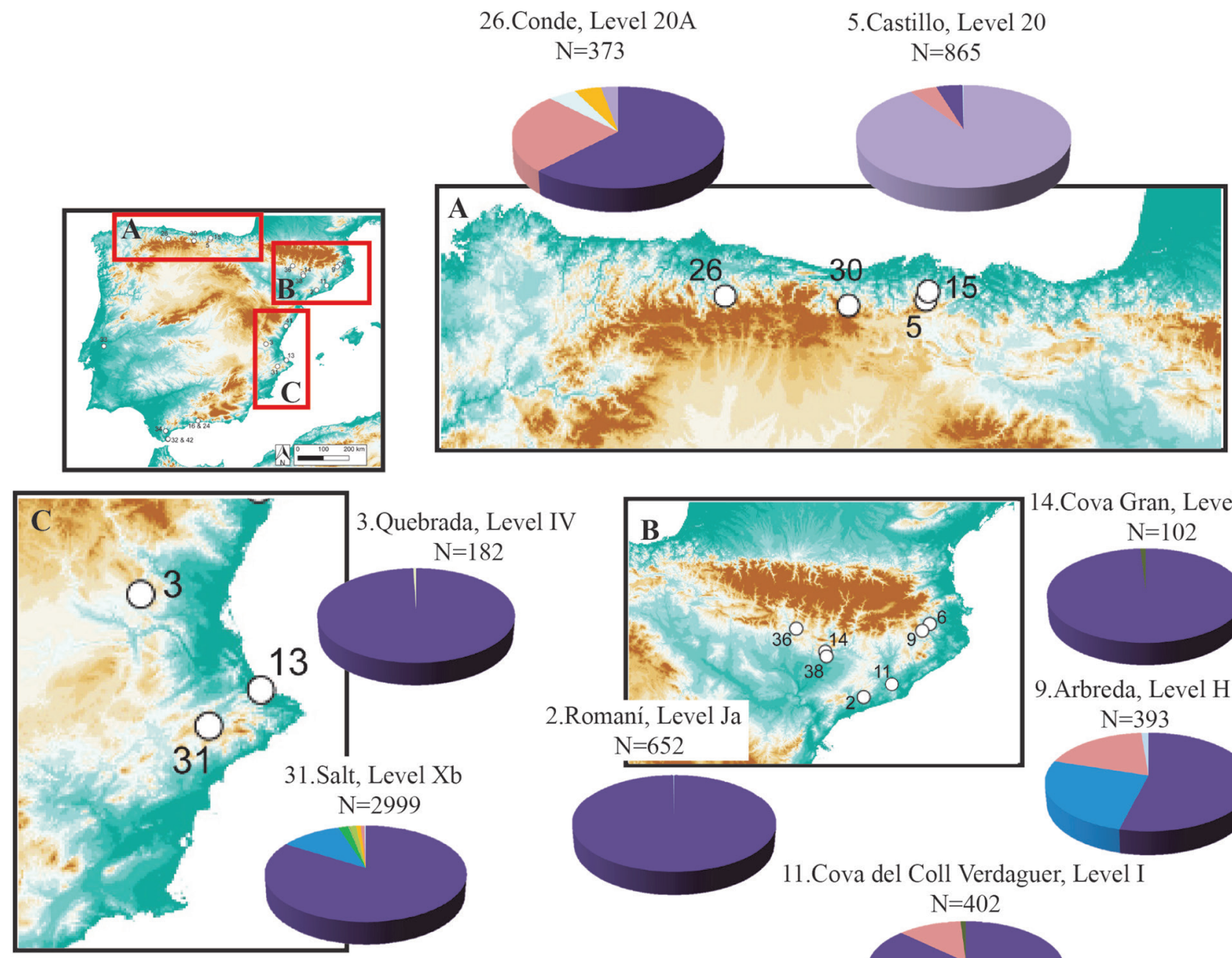

11.Cova del Coll Verdaguer, Level I

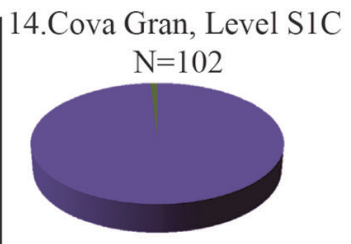

9.Arbreda, Level $\mathrm{H}$
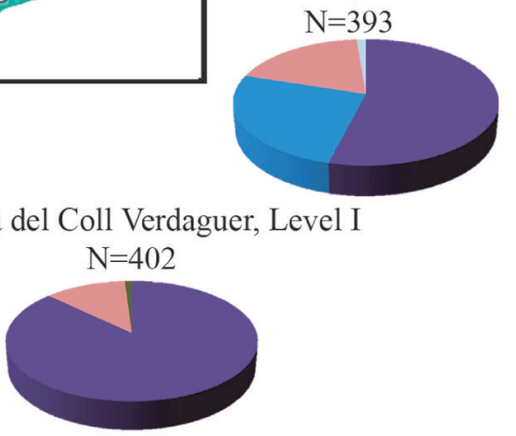

Cryophilous pines
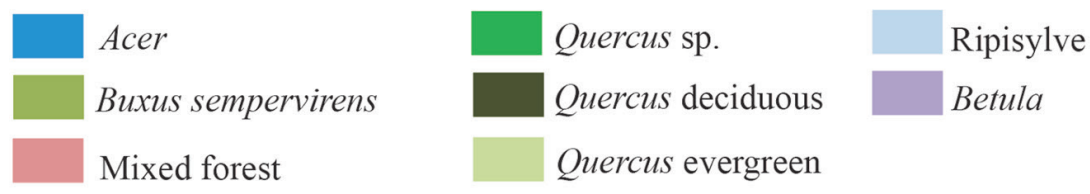

Fig. 5. Available anthracological data during MIS 3 period in Iberia. Numbers of sites refer to Table 1. / Datos antracológicos disponibles para el MIS 3 en la península Ibérica. Los números se corresponden con los sitios indicados en la Tabla 1 
the plant formations mentioned. In northeast Iberia (Fig. 5b), anthracological data from Cova de l'Arbreda, level H (Ros, 1985), Abric Romaní, level Ja (Allué, 2002), Fuentes de San Cristóbal, level G (Allué, 2002), Roca dels Bous, level R3 (Terradas et al., 1993), Cova 120, level IV (Agustí et al., 1991), Cova Gran, level S1C (Allué et al., 2018) and Cova del Coll Verdaguer, level I (Allué et al., 2017) come mainly from hand-picking sampling, excepting Cova de l'Arbreda. They all reflect the dominance of Pinus nigra-sylvestris, together with the presence of junipers, evergreen / deciduous oaks, the mixed forest and riverine taxa. The almost absolute dominance of cryophilous pines at Abric Romaní and Cova Gran should be interpreted with caution since wood charcoal fragments from these sites were recovered by hand-picking methods. Indeed, flotation methods at Cova de l'Arbreda -an archaeological site with similar altitude than Abric Romaní or Roca dels Bous- allowed obtaining a more heterogeneous anthracological assemblage with a high presence of Maple. In eastern and southeastern Iberia (Fig. 5c), significant available data come from Quebrada, level IV (Badal et al., 2012a) and El Salt, level Xb (Vidal-Matutano et al., 2018), showing a general trend consisting in the dominance of cryophilous pines together with the presence of Maple, Oak forest and the mixed forest. In this sense, qualitative differences between both sites may come from the different number of wood charcoal fragments identified and published until now, as there are no differences in the sampling methods applied or the biogeographical conditions. Data from Cova Foradà, level C5 (Badal, 1984) and Tossal de la Font, level Ila (Olària et al., 2004-2005) represent values too low to have palaeoecological representativeness. In western Iberia the only available anthracological data come from Gruta da Oliveira, levels 14-15 (Badal et al., 2012a), even though they are too scarce to be representative of the area. Despite this, the few available data seem to be consistent with other Iberian areas, i.e. Pinus nigra-sylvestris dominance with junipers and heliophilous taxa. Finally, even though anthracological data from Gorham's Cave, level IV, and Vanguard Cave, level IV (Gale and Garruthers, 2000) are not published in absolute values, the presence of warm pines identified as Pinus pinea-pinaster (stone-pinaster pine) together with the presence of Olea europaea and Mediterranean shrubland taxa place the south of Iberia as one of the warmer areas in Europe during MIS 3 (Finlayson and Carrión, 2007). This assumption is confirmed by the presence of Olea europaea macroremains at other sites like Cueva del Boquete de Zafarraya, level II (Lebreton et al., 2006) and Higueral de la Valleja, level VI, where an olive nutshell recovered was dated at 42630-41390 cal. BP (Jennings et al., 2009).

\subsection{Hand-picking vs. flotation: Are both methods equally representative of the local landscape?}

As Table 1 shows, in most of the Middle Palaeolithic sites where anthracological data has been obtained hand-picking or flotation methods have been applied, although the recovering of wood charcoal fragments by hand still constitutes the most used sampling method (Fig. 6).

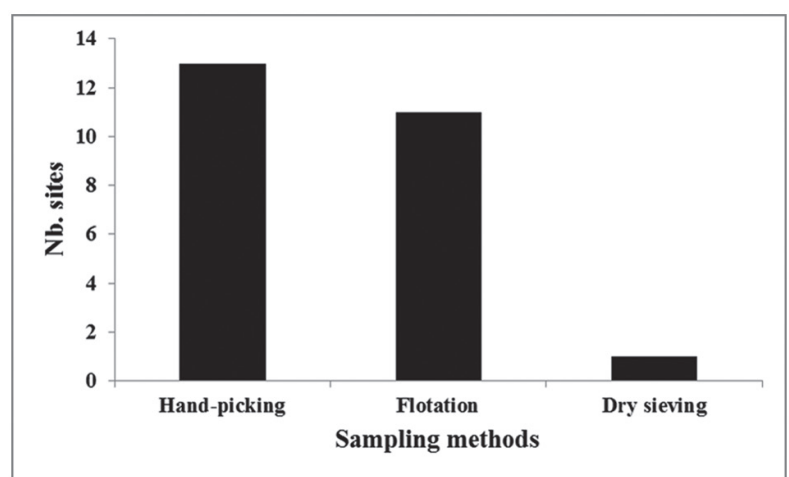

Fig. 6. Sampling methods used in Middle Palaeolithic sites from Iberia (data from Table 1). / Métodos de muestreo utilizados en yacimientos del Paleolítico medio de la península Ibérica (datos extraídos de la Tabla 1).

In order to reveal the danger involved from extracting palaeoecological inferences from those wood charcoal assemblages recovered by hand-picking, a comparative study between these two sampling methods is presented concerning units IX and Xa from EI Salt, a MIS 3 Palaeolithic site located at Eastern Iberia (Vidal-Matutano, 2017; Vidal-Matutano et al., 2017b; Vidal-Matutano et al., 2018) (Table 2). The aim of this comparative study has been to assess if the palaeoecological data obtained from each sampling method is representative of the assemblage and if there is a statistical relationship. Thus, the Jaccard Index comparing the sampling methods in each unit allowed observing a trend towards dissimilarity (Table 3). Accordingly, the application of one or other method would not mean obtaining the same results. The spatial distribution of the hand-picked wood charcoal fragments from unit IX together with the frequency map of the anthracological remains recovered by flotation methods clearly reflects the squares where a double sampling method was applied and those where the material was only recovered by hand (Fig. 7). Hence, hand-picking of wood charcoal has provided the almost absolute predominance of the most frequent taxon (Pinus nigra-sylvestris) and the botanical identification of different taxa recovered as a single one (Labiatae + Pinus nigra-sylvestris or Cistaceae + Pinus sp.). The frequency map with wood charcoal fragments retrieved by flotation methods indicates a higher density of anthracological remains in A5, B5 and A6 squares, where some of the combustion structures from unit IX are located. The $\mathrm{R}$ value for hand-picking results points out to a clustered distribution pattern $(R=0.39)$, whereas $R$ value for flotation results indicates a random distribution pattern $(R=0.66)$. Both values have a statistical significance of $99 \%(C \geq 2.58)$.

Regarding unit Xa from the same site, botanical identification of the hand-picked wood charcoal frag- 


\begin{tabular}{|c|c|c|c|c|c|c|c|c|}
\hline \multirow{3}{*}{$\begin{array}{c}\text { Units } \\
\text { Sampling method } \\
\text { Taxa }\end{array}$} & \multicolumn{4}{|c|}{ IX } & \multicolumn{4}{|c|}{$\mathrm{Xa}$} \\
\hline & \multicolumn{2}{|c|}{ Flotation } & \multicolumn{2}{|c|}{ Hand-picking } & \multicolumn{2}{|c|}{ Flotation } & \multicolumn{2}{|c|}{ Hand-picking } \\
\hline & $n$ & $\%$ & $n$ & $\%$ & $n$ & $\%$ & $n$ & $\%$ \\
\hline Acer sp. & 10 & 6,45 & 2 & 2 & 43 & 7,30 & 12 & 3,88 \\
\hline Angiosperms & 4 & 2,58 & & & 9 & 1,53 & 1 & 0,32 \\
\hline Buxus sempervirens & 1 & 0,65 & 1 & 1 & & & & \\
\hline Conifers & 15 & 9,68 & 4 & 4 & 67 & 11,38 & 9 & 2,91 \\
\hline Ephedrasp. & & & & & 2 & 0,34 & 1 & 0,32 \\
\hline Fabaceae & 1 & 0,65 & & & & & & \\
\hline Juniperus sp. & 11 & 7,10 & & & 26 & 4,41 & 2 & 0,65 \\
\hline Monocotyledoneae & & & & & 1 & 0,17 & & \\
\hline Olea europaea & & & & & 4 & 0,68 & & \\
\hline cf. Pinus nigra-sylvestris & & & & & 2 & 0,34 & & \\
\hline Pinus nigra-sylvestris & 105 & 67,74 & 93 & 93 & 407 & 69,10 & 281 & 90,94 \\
\hline Pistacia sp. & 1 & 0,65 & & & 1 & 0,17 & & \\
\hline cf. Prunus sp. & & & & & 1 & 0,17 & & \\
\hline cf. Quercus sp. & & & & & 2 & 0,34 & & \\
\hline Quercus sp. & 3 & 1,94 & & & 13 & 2,21 & 3 & 0,97 \\
\hline Quercus deciduous & & & & & 4 & 0,68 & & \\
\hline Quercus evergreen & & & & & 2 & 0,34 & & \\
\hline Salix-Populus & 4 & 2,58 & & & 5 & 0,85 & & \\
\hline Total charcoal & 155 & 100 & 100 & 100 & 589 & 100 & 309 & 100 \\
\hline Total taxa & 8 & & 3 & & 11 & & 5 & \\
\hline
\end{tabular}

Table 2: Anthracological data from units IX and Xa of El Salt based on the sampling methods. / Datos antracológicos procedentes de las unidades IX y Xa de El Salt según los métodos de muestreo.

\begin{tabular}{|c|c|}
\hline Unit & Jaccard Index \\
\hline $\mathrm{IX}$ & 0,4 \\
\hline $\mathrm{Xa}$ & 0,5 \\
\hline
\end{tabular}

Table 3: Jaccard Index results considering the sampling methods applied in units IX and Xa from El Salt. / Resultados del Índice de Jaccard considerando los métodos de muestreo aplicados en las unidades IX y Xa de El Salt

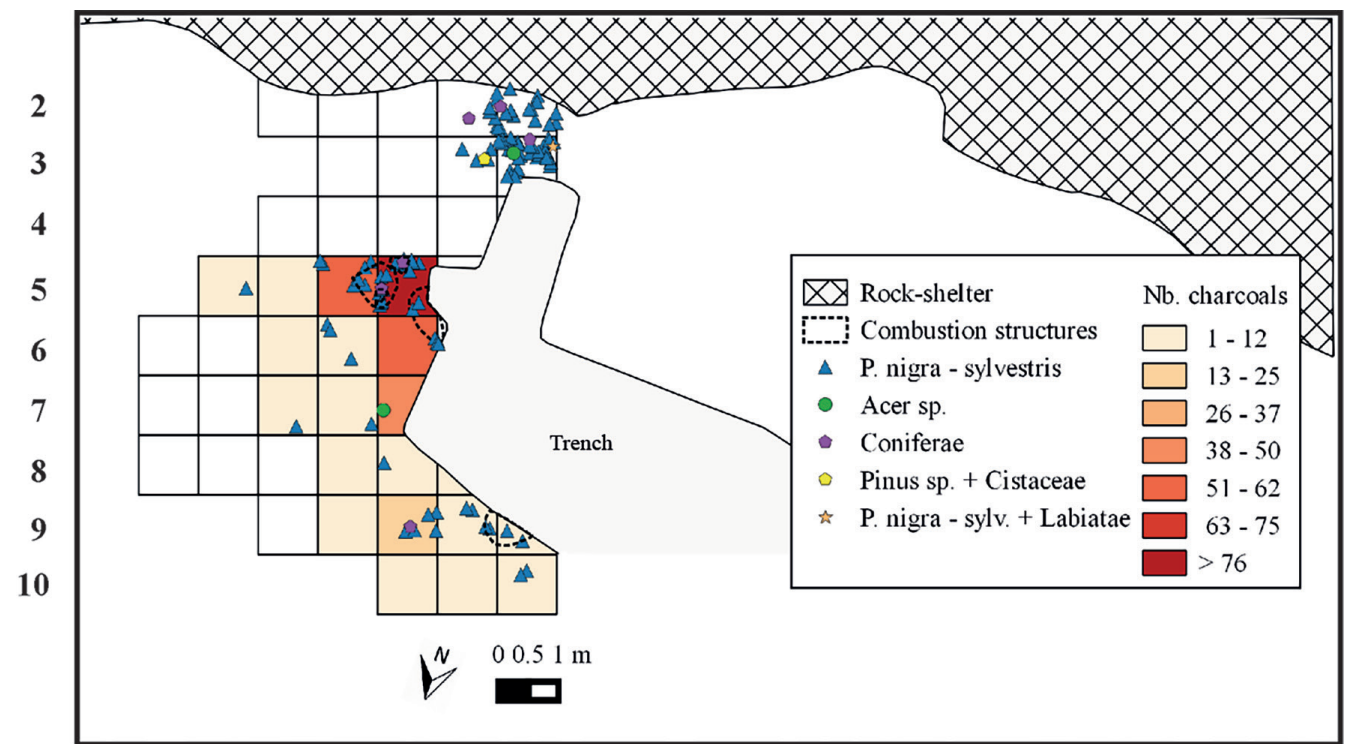

$\begin{array}{lllllll}\text { E } & \text { D } & \text { C } & \text { B } & \text { A } & \text { Z } & \text { Y }\end{array}$
Fig. 7. Spatial distribution of the hand-picked charcoal fragments (symbols) and frequency map of the charcoal fragments from flotation in unit IX. White squares represent the lack of anthracological data. / Distribución espacial de los fragmentos de carbón recogidos a mano (símbolos) y mapa de frecuencias de los carbones recuperados en flotación para la unidad IX. Los cuadros blancos representan la ausencia de datos antracológicos. 
ments revealed the collection of 2 - 3 different taxa considered as a single fragment, together with the recovering of small burnt bones or blackish sediment as charcoal during field work (Fig. 8 A). The spatial distribution of anthracological remains from flotation allowed observing a not so clustered pattern and a greater recovering of material (Fig. 8 B). $\mathrm{R}$ value for hand-pic- king results is located in the limit between a clustered and random distribution $(R=0.55)$, possibly due to the great effort made during the manual recovering of wood charcoal. Besides this, the distribution pattern of wood charcoal from flotation clearly tends to randomness ( $R$ $=0.66)$. Both values have a statistical significance of $99 \%(C \geq 2.58)$.

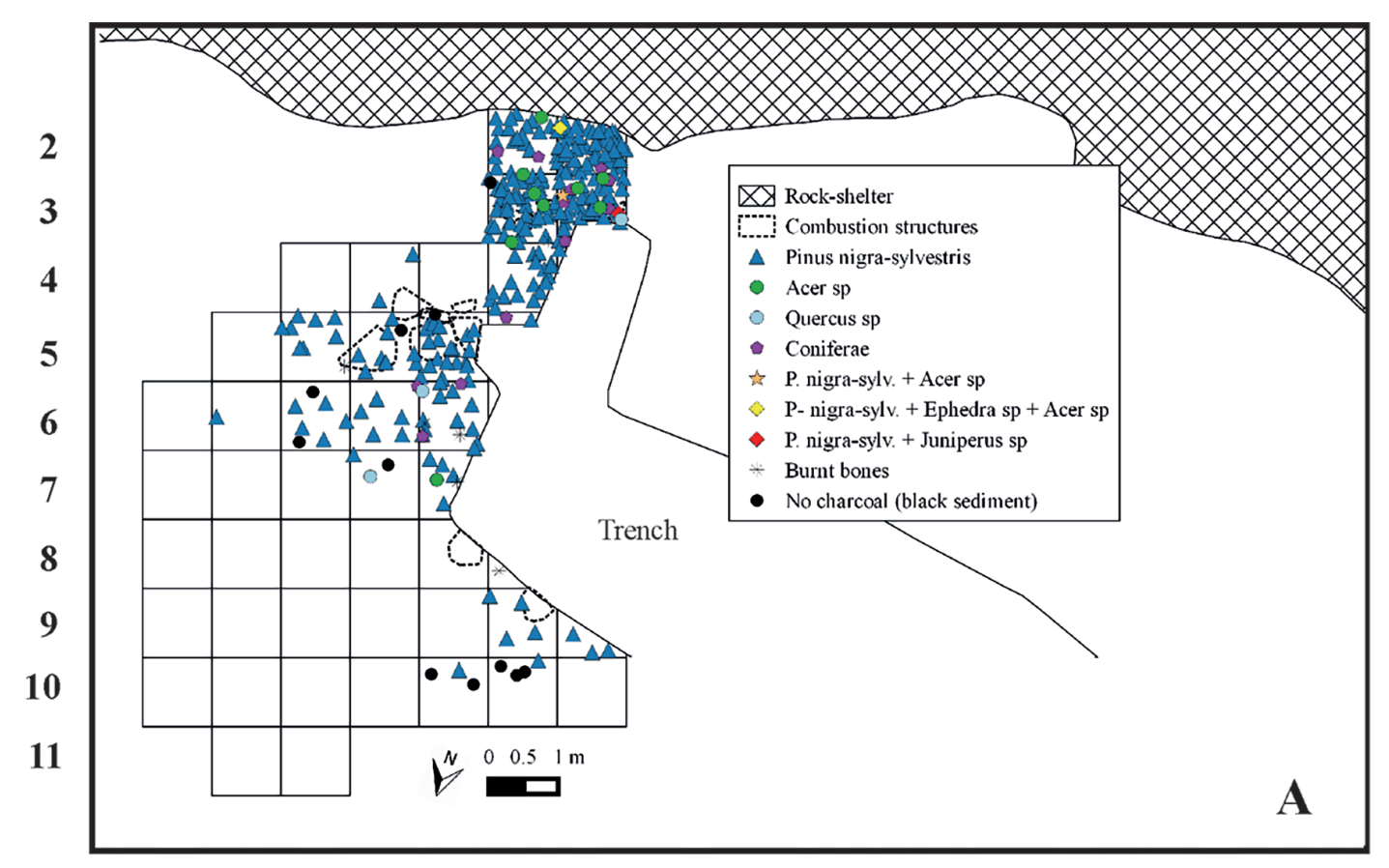

\section{E}

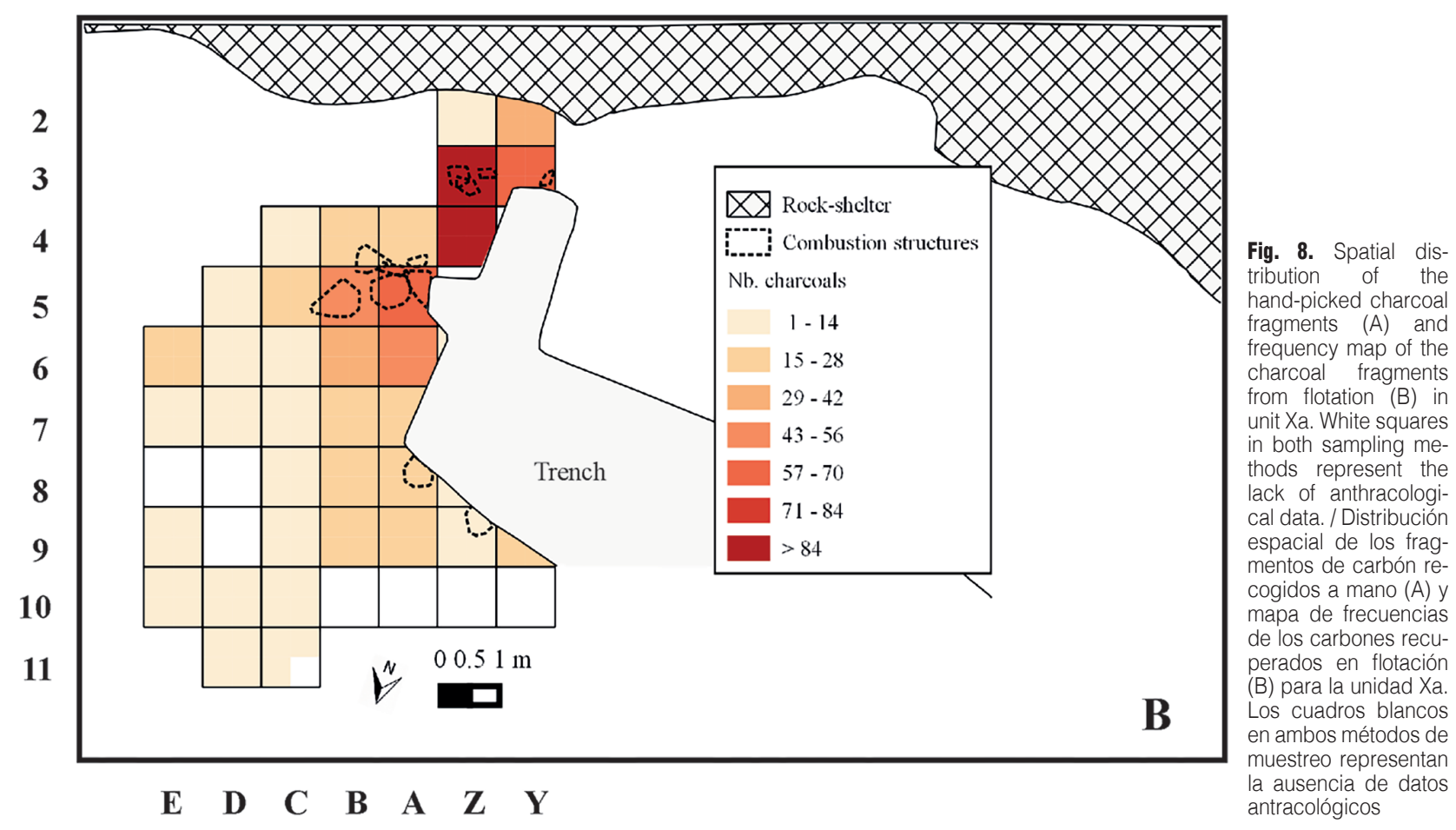


Finally, the analysis of the spatial distribution of anthracological remains based on size groups has shown that $95 \%$ of the total hand-picked assemblage corresponds to the largest size groups (> $4 \mathrm{~mm}$ y $2-4 \mathrm{~mm}$ ) (fig. $9 \mathrm{~A}$ ), which correspond to the two more frequent taxa from this unit: Pinus nigra-sylvestris and Acer sp. (fig. 9 B). This shows that hand-picking sampling leads to the overrepresentation of the most frequent taxa (cryophilous pines) and to the loss of valuable palaeoecological data related to the accompanying plant formations (Badal and Heinz, 1989; Chabal, 1997, 1992). In addition to this, hand-picking requires a much greater effort to achieve the efficiency shown by flotation methods.

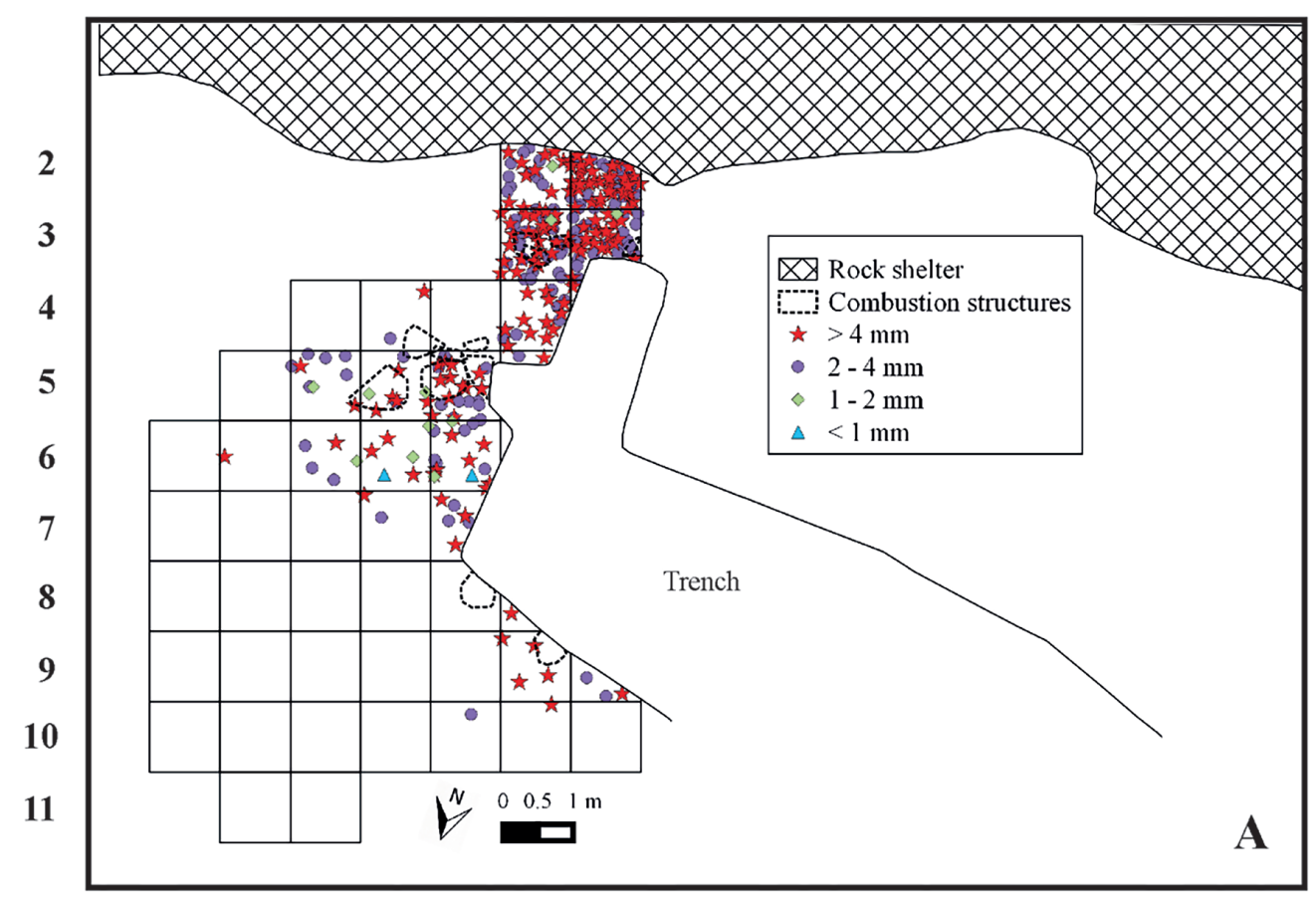

$\begin{array}{lllllll}\text { E } & \mathbf{D} & \mathbf{C} & \mathbf{B} & \mathbf{A} & \mathbf{Z} & \mathbf{Y}\end{array}$

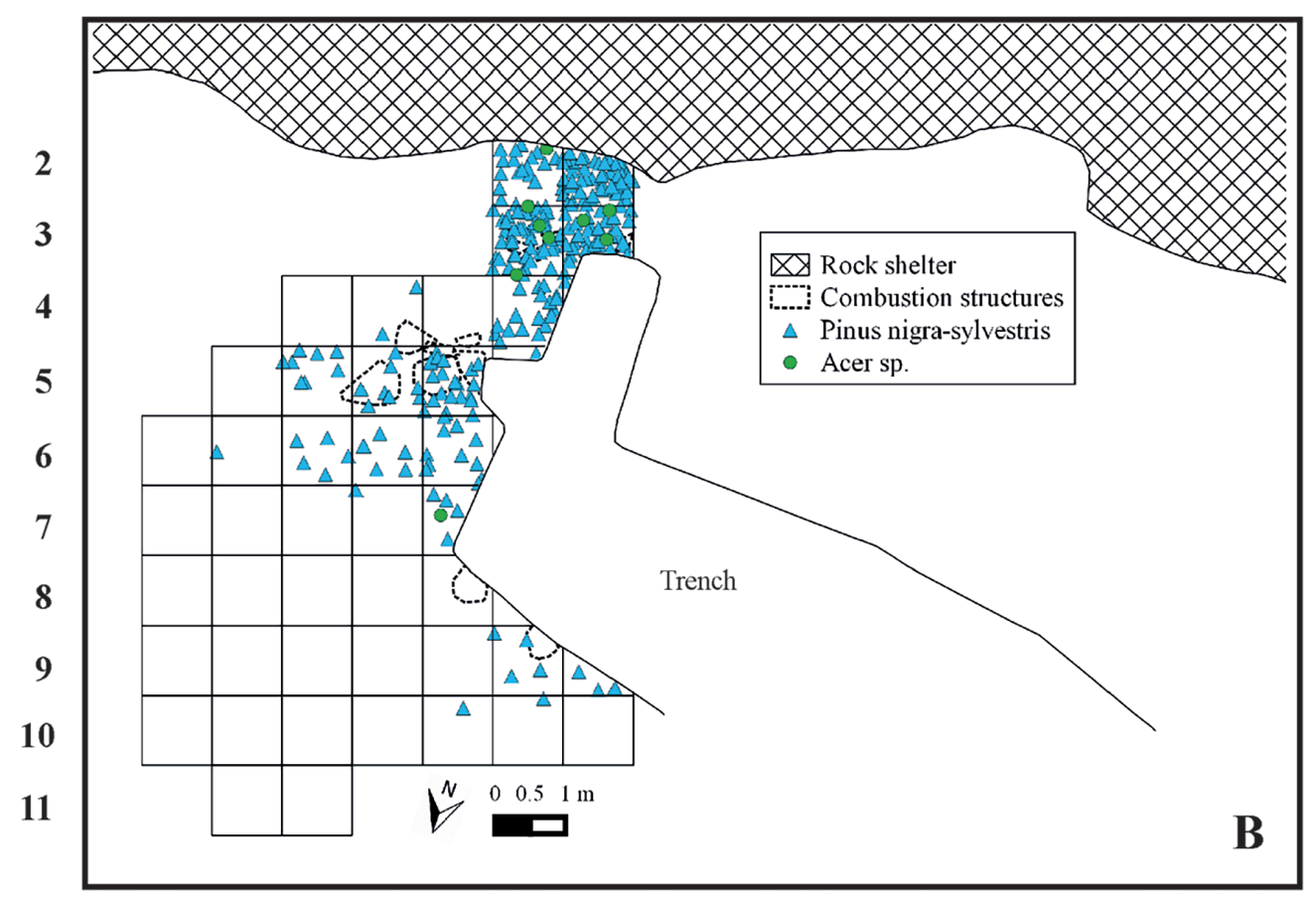

Fig. 9. Spatial distribution of the hand-picked charcoal fragments in unit Xa: (A) size groups and (B) predominant taxa in Distribución espacial de los fragmentos de carbón recogidos a mano en la unidad Xa: (A) grupos de tamaños y (B) taxo$\begin{array}{lllllll}\text { E } & \mathbf{D} & \mathbf{C} & \mathbf{B} & \mathbf{A} & \mathbf{Z} & \mathbf{Y}\end{array}$ nes dominantes en el conjunto. 


\section{CONCLUSIONS}

Available anthracological data from Middle Palaeolithic contexts in Iberia are still very scarce. The fragmented information retrieved reflects the existence of areas with greater tradition in wood charcoal analyses (northern, northeastern and eastern Iberia) compared with other less known areas presenting little or absence of data (southern, western and central Iberia). The existing gaps are more common during MIS 6, 5 and 4 periods whereas more recent chronologies (MIS 3) show an increase in the available data. Despite the use of different sampling methods with different resolution degrees during the recovery of wood charcoal fragments, the predominance of Pinus nigra-sylvestris since, at least, MIS 6 period is remarkable. This would indicate the widespread presence of cryophilous pine woodlands during the Upper Pleistocene in Iberia pointing to the prevalence of supramediterranean conditions (MAT $=8-13^{\circ} \mathrm{C}$ ). Although the predominance of cryophilous pines in Iberia is confirmed during most of the Middle Palaeolithic period, data from the little known MIS 4 indicate large open plant formations of junipers and heliophilous taxa in, at least, eastern Iberia. FinaIly, available data from MIS 3 anthracological contexts allow considering the existence of nuances between the northern Iberia with the presence of more humid components, the northeastern and eastern Iberia with drier bioindicators and southern Iberia with warmer flora. Further research on charcoal analyses from Middle Palaeolithic sites in Iberia preferably sampled with flotation methods will contribute meaningful insights into past landscape dynamics over time allowing the detection of regional and biogeographical nuances.

\section{ACKNOWLEDGEMENTS}

This work was carried out with the financial support of a VALi+d Predoctoral grant (ACIF/2013/260). P. Vidal-Matutano is funded by the APOSTD Postdoctoral grant (APOSTD/2017/126, Generalitat Valenciana). The archaeological research from El Salt was funded under the Spanish Government projects HAR2012-32703 and HAR2015-68321-P (MICINN-FEDER/UE) and Direcció General de Cultura (Conselleria d'Educació, Cultura i Esports, Generalitat Valenciana). The author is very grateful to the reviewers for helpful comments on the manuscript.

\section{REFERENCES}

Agustí, B., Alcalde, G., Güell, A., Juan-Muns, N., Rueda, J.M., Terradas, X., 1991. La cova 120, parada de caçadors-recol·lectors del Paleolític mitjà. Cypsela IX, 7-20.

Allué, E., 2002. Dinámica de la vegetación y explotación del combustible leñoso durante el Pleistoceno superior y el Holoceno del noreste de la península Ibérica a partir del análisis antracológico. Unpublished Doctoral Dissertation. Universitat Rovira i Virgili.
Allué, E., Martínez-Moreno, J., Roy, M., Benito-Calvo, A., Mora, R., 2018. Montane pine forests in NE Iberia during MIS 3 and MIS 2. A study based on new anthracological evidence from Cova Gran (Santa Linya, Iberian Pre-Pyrenees). Review of Palaeobotany and Palynology 258, 62-72.

Allué, E., Picornell-Gelabert, LI., Daura, J., Sanz, M., 2017. Reconstruction of the palaeoenvironment and anthropogenic activity from the Upper Pleistocene / Holocene anthracological records of the NE Iberian Peninsula (Barcelona, Spain). Quaternary International 457, 172-189.

Allué, E., Solé, A., Burguet-Coca, A., 2016. Fuel exploitation among Neanderthals based on the anthracological record from Abric Romaní (Capellades, NE Spain). Quaternary International https://doi.org/10.1016/j.quaint.2015.12.046.

Arrizabalaga, A., 2014. Lezetxiki (Arrasate, Gipúzkoa). In: Carbonell, E., Arsuaga, J.L., Bermúdez de Castro, J.M. (Eds.), Los cazadores-recolectores del Pleistoceno y del Holoceno en Iberia y el Estrecho de Gibraltar: Estado actual del conocimiento del registro arqueológico, 105-109, Universidad de Burgos and Fundación Atapuerca. Burgos.

Arsuaga, J.L., Baquedano, E., Pérez-González, A., Sala, N., Quam, R.M., Rodríguez, L., García, R., García, N., Álvarez-Lao, D.J., Laplana, C., Huguet, R., Sevilla, P., Maldonado, E., Blain, H.-A., Ruiz-Zapata, M.B., Sala, P., Gil-García, M.J., Uzquiano, P., Pantoja, A., Márquez, B., 2012. Understanding the ancient habitats of the last-interglacial (late MIS 5) Neanderthals of central Iberia: Paleoenvironmental and taphonomic evidence from the Cueva del Camino (Spain) site. Quaternary International 275, 55-75.

Badal, E., 1984. Contribución al estudio de la vegetación prehistórica del sur de Valencia y norte de Alicante a través del análisis antracológico. Unpublished Master Dissertation. Universitat de València.

Badal, E., 1990. Aportaciones de la antracología al estudio del paisaje vegetal y su evolución en el Cuaternario reciente, en la costa mediterránea del País Valenciano y Andalucía (18.000-3.000 BP). Unpublished Doctoral Dissertation. Universitat de València.

Badal, E., 1992. L'anthracologie préhistorique: à propos de certains problèmes méthodologiques. Bulletin de la Société Botanique Française 139, 167-189.

Badal, E., Carrión, Y., Figueiral, I., Rodríguez-Ariza, M.O., 2012b. Pinares y enebrales. El paisaje solutrense en Iberia. Espacio, Tiempo y Forma. Serie I. Prehistoria y Arqueología $5,259-271$

Badal, E., Heinz, C., 1989. L'analyse anthracologique des dépôts préhistoriques Pléistocène supérieur et Holocène: prélèvement et analyse des données. Bulletin Française Paléobotanique 11, 9-16.

Badal, E., Heinz, C., 1991. Méthodes utilisées en Anthracologie pour l'étude de sites préhistoriques, 17-47, BAR International Series 573.

Badal, E., Villaverde, V., Zilhão, J., 2012a. Middle Palaeolithic wood charcoal from three sites in south and west Iberia: Biogeographic implications, In: Badal, E., Carrión, Y., Macías, M., Ntinou, M. (Eds.), Wood and Charcoal. Evidence for Human and Natural History. Saguntum-Extra 13, 13-24.

Bazile-Robert, E., 1982. Données expérimentales pour l'anthracoanalyse. Études quaternaires languedociennes 2, 19-28.

Burjachs, F., López-García, J.M., Allué, E., Blain, H.-A., Rivals, F., Benàssar, M., Expósito, I. 2012. Palaeoecology of Neander- 
thals during Dansgaard-Oeschger cycles in northeastern Iberia (Abric Romaní): from regional to global scale. Quaternary International 247, 26-37.

Carrión, J.S., 1992. A palaeoecological study in the western Mediterranean area. The Upper Pleistocene pollen record from Cova Beneito (Alicante, Spain). Palaeogeography, Palaeoclimatology, Palaeoecology 92, 1-14.

Carrión, J.S., Dupré, M., 1994. Pollen data from Mousterian sites in southeastern Spain. AASP Contribution Series 29, 17-26.

Carrión, J.S., Finlayson, C., Fernández, S., Finlayson, G., Allué, E., López-Sáez, J.A., López-García, P., Gil-Romera, G., Bailey, G., González-Sampériz, P., 2008. A coastal reservoir of biodiversity for Upper Pleistocene human populations: Palaeoecological investigations in Gorham's Cave (Gibraltar) in the context of the Iberian Peninsula. Quaternary Science Reviews $27,2118-2135$.

Carrión, J.S., YII, E.I., Walker, M.J., Legaz, A.J., Chaín, C., López, A., 2003. Glacial refugia of temperate, Mediterranean and Ibero-North African flora in south-eastern Spain: New evidence from cave pollen at two Neanderthal man sites. Global Ecology and Biogeography 12, 119-129.

Carrión, Y., 2007. Woodland in the middle Ebro Valley (Spain). Dendrological analysis of archaeological timber from Bell Baker and Iron Age periods. ArcheoSciences. Revue d'Archéometrie 31, 151-161.

Caruso, L., Iriarte Avilés, E., Borrero, L.A., 2014. Tracing driftwood in archaeological contexts: Experimental data and anthracological studies at the Orejas De Burro 1 Site (Patagonia, Argentina). Archaeometry 57, 175-193.

Chabal, L., 1982. Méthodes de prélèvement des bois carbonisés protohistoriques pour l'étude des relations homme-végétation. Unpublished Master Dissertation. Université Montpellier II.

Chabal, L., 1991. L'Homme et l'évolution de la végétation méditerranéenne des âges des métaux à la période romaine; recherches anthracologiques théoriques, appliquées principalement à des sites du Bas-Languedoc. Unpublished Doctoral Dissertation. Université Montpellier II.

Chabal, L., 1992. La représentativité paléo-écologique des charbons de bois archéologiques issus du bois de feu. Bulletin de la Société Botanique de France 139, 213-236.

Chabal, L., 1997. Forêts et sociétés en Languedoc (Néolithique final, Antiquité tardive): l'anthracologie, méthode et paléoécologie. Éditions de la Maison des Sciences de l'Homme. Paris.

Chrzazvez, J., Théry-Parisot, I., Fiorucci, G., Terral, J.-F., Thibaut, B., 2014. Impact of post-depositional processes on charcoal fragmentation and archaeobotanical implications: Experimental approach combining charcoal analysis and biomechanics. Journal of Archaeological Science 44, 30-42.

Cortés-Sánchez, M., Morales-Muñiz, A., Simón-Vallejo, M.D., Bergadà-Zapata, M.M., Delgado-Huertas, A., López-García, P., López-Sáez, J.A., Lozano-Francisco, M.C., Riquelme-Cantal, J.A., Roselló-Izquierdo, E., 2008. Palaeoenvironmental and cultural dynamics of the coast of Málaga (Andalusia, Spain) during the Upper Pleistocene and early Holocene. Quaternary Science Reviews 27, 2176-2193.

Costa, M., Morla, C., Sainz, H., 2005. Los bosques ibéricos: Una interpretación geobotánica. Planeta, Barcelona.

Dansgaard, W., Johnsen, S., Clausen, H., Dahl-Jensen, D., Gundestrup, N., Hammer, C., Hvidberg, C., Steffensen, J., Sveinbjörnsdottir, A., Jouzel, J., 1993. Evidence for general instability of past climate from a 250-kyr ice-core record. Nature 364, 218-220.

Daura, J., Sanz, M., Julià, R., García-Fernández, D., Fornós, J., Vaquero, M., Allué, E., López-García, J., Blain, H., Ortiz, J., 2015 Cova del Rinoceront (Castelldefels, Barcelona): A terrestrial record for the Last Interglacial period (MIS 5) in the Mediterranean coast of the Iberian Peninsula. Quaternary Science Reviews 114, 203-227.

Dupré, M., 1988. Palinología y Paleoambiente. Nuevos datos españoles. Referencias. Serie de Trabajos Varios del Servicio de Investigación Prehistórica 84, Valencia.

Figueiral, I., 1990. Le Nord-Ouest du Portugal et les modifications de l'ecosysteme, du Bronze final á l'époque romaine, d'aprés l'anthracoanalyse des sites archéologiques. Unpublished Doctoral Dissertation. Université des Sciences et Techniques du Languedoc. Montpellier.

Figueiral, I., 1992. Méthodes en anthracologie: étude de sites du Bronze final et de l'âge du fer du nord-ouest du Portugal. Bulletin de la Société Botanique de France 139, 191-204.

Finlayson, C., Carrión, J.S., 2007. Rapid ecological turnover and its impact on Neanderthal and other human populations. Trends in Ecology and Evolution 22, 213-222.

Gale, R., Carruthers, W., 2000. Charcoal and charred seed remains from Middle Palaeolithic levels at Gorham's and Vanguard Caves, In: Stringer, C., Barton, R., Finlayson, C. (Eds.), Neanderthals on the Edge, 207-210. Oxbow books.

González-Sampériz, P., 2004. Evolución paleoambiental del sector central de la cuenca del Ebro durante el Pleistoceno superior y Holoceno. Instituto Pirenaico de Ecología - CSIC. Zaragoza.

Heinrich, H., 1988. Origin and consequences of cyclic ice rafting in the northeast Atlantic Ocean during the past 130,000 years. Quaternary Research 29, 142-152.

Heinz, C., 1988. Dynamique des végétations holocènes en Méditerranée nord occidentale d'après l'anthracoanalyse de sites préhistoriques: méthodologie et paléoécologie. Unpublished Doctoral Dissertation. Université Montpellier II.

Henry, A., Boboeuf, M., 2016. Environnement ligneux et gestion du bois de feu au cours du Mésolithique au Clos de Poujol (Campagnac, Aveyron). Bulletin de la Société Préhistorique Française 113, 5-30

Henry, A., Théry-Parisot, I., 2014. From Evenk campfires to prehistoric hearths: charcoal analysis as a tool for identifying the use of rotten wood as fuel. Journal of Archaeological Science 52, 321-336.

Iriarte, M.J., 2000. El entorno vegetal del yacimiento paleolítico de Labelo Koba (Arrasate, País Vasco): análisis polínico. Munibe Antropologia-Arkeologia 52, 89-106.

Jennings, R., Pacheco, F.G., Barton, R., Collcutt, S., Gale, R., Gleed-Owen, C., López, J.G., Higham, T., Parker, A., Price, C., 2009. New dates and palaeoenvironmental evidence for the Middle to Upper Palaeolithic occupation of Higueral de Valleja Cave, southern Spain. Quaternary Science Reviews 28, 830-839.

Lebreton, V., Renault-Miskovsky, J., Carrión, J.S., Dupré, M., 2006. Étude palynologique du remplissage de la grote du Boquete de Zafarraya, In: La Grotte Boquete de Zafarraya, 629660, Monographies Institut de Paléontologie Humaine.

Leroi-Gourhan, A., 1966. Análisis polínico de la Cueva del Otero. In: González Echegaray, J., García Guinea, M.A., Begines Ramírez, A. (Eds.), Excavaciones en la Cueva de Otero (San- 
tander) Excavaciones arqueológicas en España, 83-85. Ministerio de Educación, Madrid.

López-García, J.M., Blain, H.-A., Burjachs, F., Ballesteros, A., Allué, E., Cuevas-Ruiz, G.E., Rivals, F., Blasco, R., Morales, J.I., Hidalgo, A.R., 2012. A multidisciplinary approach to reconstructing the chronology and environment of southwestern European Neanderthals: The contribution of Teixoneres cave (Moià, Barcelona, Spain). Quaternary Science Reviews 43, 33-44.

Marguerie, D., Hunot, J.-Y., 2007. Charcoal analysis and dendrology: data from archaeological sites in north-western France. Journal of Archaeological Science 34, 1417-1433.

Martínez-Moreno, J., Mora, R., de la Torre, I., 2010. The Middle-to-Upper Palaeolithic transition in Cova Gran (Catalunya, Spain) and the extinction of Neanderthals in the Iberian peninsula. Journal of Human Evolution 58, 211-226.

Olària, C., Carbonell, E., Ollé, A., Allue, E., Bennàsar, L., Bischoff, J.L., Burjachs, F., Cáceres, I., Expósito, I., López-Polín, L., 2004-2005. Noves intervencions al jaciment pleistocènic de la Cova de Dalt del Tossal de la Font (Vilafamés, Castelló). Quaderns de Prehistòria i Arqueologia de Castelló 24, 9-26.

Rasmussen, S.O., Andersen, K.K., Svensson, A., Steffensen, J.P., Vinther, B.M., Clausen, H.B., Siggaard-Andersen, M., Johnsen, S.J., Larsen, L.B., Dahl-Jensen, D., 2006. A new Greenland ice core chronology for the last glacial termination. Journal of Geophysical Research: Atmospheres 111, 1984-2012.

Rasmussen, S.O., Bigler, M., Blockley, S.P., Blunier, T., Buchardt, S.L., Clausen, H.B., Cvijanovic, I., Dahl-Jensen, D., Johnsen, S.J., Fischer, H., 2014. A stratigraphic framework for abrupt climatic changes during the Last Glacial period based on three synchronized Greenland ice-core records: refining and extending the INTIMATE event stratigraphy. Quaternary Science Reviews 106, 14-28.

Rivas Martínez, S., 1987. Memoria del mapa de series de vegetación de España: 1:400.000. ICONA.

Ros T., 1985. Contribució antracoanalítica a l'estudi de l'entorn vegetal de l'home del Paleolític superior a l'Edat de Ferro a Catalunya. Unpublished Master Dissertation. Universitat Autònoma de Barcelona.

Rosell J., Blasco, R, Rivals, F., Chacón, M.G., Blain, H.-A., López-García, J.M., Picin, A., Camarós, E., Rufà, A., Sánchez A.M., Gómez, G., Arilla, M., Gómez de Soler, B., Bustos, G., Iriarte, E., Cebrià. A., 2014. Cova del Toll y Cova de les Teixoneres (Moià, Barcelona). In: Carbonell, E., Arsuaga, J.L., Bermúdez de Castro, J.M. (Eds.), Los cazadores-recolectores del Pleistoceno y del Holoceno en Iberia y el Estrecho de Gibraltar: Estado actual del conocimiento del registro arqueológico, 302-307. Universidad de Burgos and Fundación Atapuerca. Burgos.

Ruiz Zapata, M., Gómez González, C., Gil García, M., López Sáez, J., Baquedano, E., Pérez González, A., Arsuaga, J., 2008. Comparación de las secuencias polínicas del Holoceno reciente del yacimiento arqueopaleontológico de El Calvero de la Higuera (Pinilla del Valle, Madrid) y de la turbera de Rascafría (Madrid). Geotemas 10, 1-483.

Sáenz de Buruaga, P., 2014. Cueva de Arrillor (Araba, País Vasco): notas de su evolución climática e industrial durante el Pleistoceno superior, In: Carbonell, E., Bermúdez de Castro, J.M., Arsuaga, J.L. (Eds.), Los cazadores-recolectores del Pleistoceno y del Holoceno en Iberia y el Estrecho de Gibraltar: Estado actual del conocimiento del registro arqueológico, 141-147. Universidad de Burgos and Fundación Atapuerca. Burgos.
Sánchez Goñi, M.F., D’Errico, F., 2005. La historia de la vegetación y el clima del último ciclo climático (OIS5-OIS1, 140.00010.000 años BP) en la península Ibérica y su posible impacto sobre los grupos paleolíticos, In: Neandertales Cantábricos: Estado de la cuestión. Monografías del Museo Nacional y Centro de Investigación de Altamira 20, 115-129.

Sánchez Goñi, M.F., Eynaud, F., Turon, J., Shackleton, N., 1999. High resolution palynological record of the Iberian margin: direct land-sea correlation for the Last Interglacial complex. Earth and Planetary Science Letters 171, 123-137.

Sánchez-Goñi, M.F., 1991. Analyses palynologiques des remplissages de grotte de Lezetxiki, Labeko et Urtiaga (Pays Basque espagnol). Leur place dans le cadre des sequences polliniques de la côte cantabrique et des Pyrénées occidentales. De la taphonomie pollinique á la reconstitution de l'environnement. Unpublished Doctoral Dissertation. Musée National d'Histoire Naturelle á l'Institut de Paleontologie Humaine, Paris.

Sánchez-Goñi, M.F., 1994. L'environnement de l'homme préhistorique dans la région cantabrique d'après la taphonomie pollinique des grottes. L'Anthropologie 98, 379-417.

Shackleton, N., 1969. The last interglacial in the marine and terrestrial records. Proceedings of the Royal Society of London B: Biological Sciences 174, 135-154.

Terradas, X., Mora, R., Martínez, J., Casellas, S., 1993. La Roca dels Bous en el contexto de la transición Paleolítico medio-superior en el NE de la península Ibérica, In: Cabrera Valdés, V. (Ed.), El origen del hombre moderno en el suroeste de Europa, 247-257.UNED.

Théry-Parisot, I., 2005. Propriétés combustibles des ossements. Gallia Préhistoire 47, 235-254.

Théry-Parisot, I., 2001. Économie des combustibles au Paléolithique. Expérimentation, anthracologie, taphonomie, D.D.A. CNRS-Editions.

Théry-Parisot, I., 2002 Fuel management (bone and wood) during the Lower Aurignacian in the Pataud rock shelter (Lower Palaeolithic, Les Eyzies de Tayac, Dordogne, France). Contribution of experimentation. Journal of Archaeological Science 29, 1415-1421.

Théry-Parisot, I., Chabal, L., Chrzavzez, J., 2010. Anthracology and taphonomy, from wood gathering to charcoal analysis. A review of the taphonomic processes modifying charcoal assemblages in archaeological contexts. Palaeogeography, Palaeoclimatology, Palaeoecology 291, 142-153.

Théry-Parisot, I., Henry, A., 2012. Seasoned or green? Radial cracks analysis as a method for identifying the use of green wood as fuel in archaeological charcoal. Journal of Archaeological Science 39, 381-388.

Thiébault, S., 1988. L'homme et le milieu végétal. Analyses anthracologiques de six gisements des Préalpes au Tardi-et au Postglaciaire. Documents d'Archéologie Française 15, 7-110.

Utrilla, P., Mazo, C., Domingo, R., 2014. La cueva de Abauntz (Arraitz, Navarra), In: Carbonell, E., Bermúdez de Castro, J.M., Arsuaga, J.L. (Eds.), Los cazadores-recolectores del Pleistoceno y del Holoceno en Iberia y el Estrecho de Gibraltar: Estado actual del conocimiento del registro arqueológico, 135-141 Universidad de Burgos and Fundación Atapuerca. Burgos.

Uzquiano, P., 1992 L'Homme et le bois au Paléolithique en région cantabrique, Espagne. Exemples d'Altamira et d'El Buxu. Bulletin de la Société Botanique de France 139, 361-372.

Uzquiano, P., 2005. El registro antracológico durante la transición Musteriense - Paleolítico superior inicial en la Región Can- 
tábrica: vegetación, paleoambiente y modos de vida alrededor del fuego., In: Montes Barquín, R., Lasheras Corruchaga, J.A. (Eds.), Neandertales Cantábricos: Estado de la cuestión. Monografías del Museo Nacional y Centro de Investigación de Altamira 20, 255-274.

Uzquiano, P., Arbizu, M., Arsuaga, J.L., Adan, G., Aranburu, A., Iriarte, E., 2008. Datos paleoflorísticos en la cuenca media del Nalón entre 40-32 Ka. BP: Antracoanálisis de la Cueva del Conde (Santo Adriano, Asturias). Cuaternario y Geomorfología 22, 121-133.

Uzquiano, P., Yravedra, J., Zapata, B.R., Garcia, M.J.G., Sesé, C., Baena, J., 2012. Human behaviour and adaptations to MIS 3 environmental trends (> 53-30 ka BP) at Esquilleu cave (Cantabria, northern Spain). Quaternary International 252, 82-89.

Vidal-Matutano, P., 2017. Firewood and Hearths: Middle Palaeolithic woody taxa distribution from El Salt, Stratigraphic Unit Xb (Eastern Iberia). Quaternary International 457, 74-84.

Vidal-Matutano, P., Blasco, R., Sañudo, P., Fernández-Peris, J., 2017a. The anthropogenic use of firewood during the European Middle Pleistocene: Charcoal evidence from levels XIII and XI of Bolomor Cave, Eastern Iberia (230 - $160 \mathrm{ka})$. Environmental Archaeology. https://doi.org/10.1080/14614103.201 7.1406026.
Vidal-Matutano, P., Henry, A., Théry-Parisot, I., 2017b. Dead wood gathering among Neanderthal groups: Charcoal evidence from Abric del Pastor and El Salt (Eastern Iberia). Journal of Archaeological Science 80, 109-121.

Vidal-Matutano, P., Hernández, C.M., Galván, B., Mallol, C., 2015. Neanderthal firewood management: evidence from Stratigraphic Unit IV of Abric del Pastor (Eastern Iberia). Quaternary Science Reviews 111, 81-93.

Vidal-Matutano, P., Pérez-Jordà, G., Hernández, C.M., Galván, B., 2018. Macrobotanical evidence (wood charcoal and seeds) from the Middle Palaeolithic site of El Salt, Eastern Iberia: Palaeoenvironmental data and plant resources catchment areas. Journal of Archaeological Science, Reports 19, 454-464.

Woillard, G.M., 1978. Grande Pile peat bog: a continuous poIlen record for the last 140,000 years. Quaternary Research 9, $1-21$.

Zilhão, J., Ajas, A., Badal, E., Burow, C., Kehl, M., López-Sáez, J.A., Pimenta, C., Preece, R.C., Sanchis, A., Sanz, M., Weniger, G.-C., White, D., Wood, R., Angelucci, D. E., Villaverde, V., Zapata, J., 2016. Cueva Antón: A multi-proxy MIS 3 to MIS 5a palaeoenvironmental record for SE Iberia. Quaternary Science Reviews 146, 251-273. 